\title{
Projected global ground-level ozone impacts on vegetation under different emission and climate scenarios
}

\author{
Pierre Sicard $^{1}$, Alessandro Anav ${ }^{2}$, Alessandra De Marco ${ }^{3}$, and Elena Paoletti ${ }^{2}$ \\ ${ }^{1}$ ACRI-HE, Sophia Antipolis, France \\ ${ }^{2}$ Institute of Sustainable Plant Protection, National Research Council, Sesto Fiorentino, Italy \\ ${ }^{3}$ Italian National Agency for New Technologies, Energy and the Environment, C.R. Casaccia, Italy \\ Correspondence to: Pierre Sicard (pierre.sicard@acri-he.fr)
}

Received: 26 January 2017 - Discussion started: 9 March 2017

Revised: 25 August 2017 - Accepted: 11 September 2017 - Published: 12 October 2017

\begin{abstract}
The impact of ground-level ozone $\left(\mathrm{O}_{3}\right)$ on vegetation is largely under-investigated at the global scale despite large areas worldwide that are exposed to high surface $\mathrm{O}_{3}$ levels. To explore future potential impacts of $\mathrm{O}_{3}$ on vegetation, we compared historical and projected surface $\mathrm{O}_{3}$ concentrations simulated by six global atmospheric chemistry transport models on the basis of three representative concentration pathways emission scenarios (i.e. RCP2.6, 4.5, 8.5). To assess changes in the potential surface $\mathrm{O}_{3}$ threat to vegetation at the global scale, we used the AOT40 metric. Results point out a significant exceedance of AOT40 in comparison with the recommendations of UNECE for the protection of vegetation. In fact, many areas of the Northern Hemisphere show that AOT40-based critical levels will be exceeded by a factor of at least 10 under RCP8.5. Changes in surface $\mathrm{O}_{3}$ by 2100 worldwide range from about $+4-5 \mathrm{ppb}$ in the RCP8.5 scenario to reductions of about $2-10 \mathrm{ppb}$ in the most optimistic scenario, RCP2.6. The risk of $\mathrm{O}_{3}$ injury for vegetation, through the potential $\mathrm{O}_{3}$ impact on photosynthetic assimilation, decreased by 61 and $47 \%$ under RCP2.6 and RCP4.5, respectively, and increased by $70 \%$ under RCP8.5. Key biodiversity areas in southern and northern Asia, central Africa and North America were identified as being at risk from high $\mathrm{O}_{3}$ concentrations.
\end{abstract}

\section{Introduction}

Tropospheric ozone $\left(\mathrm{O}_{3}\right)$ is a secondary air pollutant; that is, $\mathrm{O}_{3}$ is not emitted as such in the air but it is formed by reactions among precursors (e.g. $\mathrm{CH}_{4}, \mathrm{VOCs}, \mathrm{NO}_{x}$ ). Ozone is an important greenhouse gas resulting in a direct radiative forcing of $0.35-0.37 \mathrm{~W} \mathrm{~m}^{-2}$ on climate (Shindell et al., 2009; Ainsworth et al., 2012). Despite significant control efforts and legislation to reduce $\mathrm{O}_{3}$ precursor emissions, tropospheric $\mathrm{O}_{3}$ pollution is still a major air quality issue over large regions of the globe (Lefohn et al., 2010; Langner et al., 2012; Young et al., 2013; Cooper et al., 2014; EEA, 2015; Sicard et al., 2016a, b; Ochoa-Hueso et al., 2017). Longrange transport of $\mathrm{O}_{3}$ and precursors of $\mathrm{O}_{3}$ can elevate the local and regional $\mathrm{O}_{3}$ background concentrations (Ellingsen et al., 2008; Sicard et al., 2009; Wilson et al., 2012; Paoletti et al., 2014; Derwent et al., 2015; Xing et al., 2015; Sicard et al., 2016a). Therefore, remote areas such as the Arctic region can be affected (Langner et al., 2012). The current surface $\mathrm{O}_{3}$ levels (35-50 ppb in the Northern Hemisphere, $\mathrm{NH}$;) are high enough to damage both forests and crops by reducing growth rates and productivity (Wittig et al., 2009; Anav et al., 2011; Mills et al., 2011; Sicard et al., 2011; Ashworth et al., 2013; Proietti et al., 2016).

Increasing atmospheric $\mathrm{CO}_{2}$, nitrogen deposition and temperatures enhance plant growth and increase primary production and greening of plants (Nemani et al., 2003; Zhu et al., 2016). At the global scale, a widespread increase of greening and net primary production (NPP) is observed over $25-50 \%$ of the vegetated area, while a decrease is observed over only $7 \%$ of the globe (Nemani et al., 2003; Zhu et al., 2016). In contrast, a previous modelling study over Europe shows how surface $\mathrm{O}_{3}$ reduces the mean annual gross primary production (GPP) by about $22 \%$ and the leaf area index (LAI) by 15-20\% (Anav et al., 2011). Similarly, Proietti et al. (2016), using different in situ measurements collected over 37 Euro- 
pean forest sites, found a GPP decrease (up to $30 \%$ ) caused by $\mathrm{O}_{3}$ during the time period of 2000-2010. At the global scale, over the time period of 1901-2100, GPP is projected to decrease by 14-23\% (Sitch et al., 2007). As a consequence of reduced photosynthetic assimilation, the total biomass of trees is estimated to be decreased by $7 \%$ under the current ground-level $\mathrm{O}_{3}$ mean concentrations ( $40 \mathrm{ppb}$ on average) and by $17 \%$ at mean $\mathrm{O}_{3}$ concentrations expected in 2100 (97 ppb based on a meta-analysis) compared to preindustrial $\mathrm{O}_{3}$ levels in NH (about $10 \mathrm{ppb}$, Wittig et al., 2009). From experiments, Wittig et al. (2009) also reported that the total tree biomass of angiosperms was reduced by $23 \%$ at $\mathrm{O}_{3}$ mean concentrations of $74 \mathrm{ppb}$ and by $7 \%$ at $92 \mathrm{ppb}$ for gymnosperms. High surface $\mathrm{O}_{3}$ levels, exceeding $40 \mathrm{ppb}$, do occur in many regions of the globe with associated economic costs of several billion dollars per year (Wang and Mauzerall, 2004; Ashmore, 2005). Ashworth et al. (2013) reported an annual loss of $3.5 \%$ for wheat (very $\mathrm{O}_{3}$ sensitive) and $1.0 \%$ for maize (more $\mathrm{O}_{3}$ tolerant) for Europe in 2010 relative to 2000, while Holland et al. (2006) estimated a EUR 4.5 billion loss in the production of 23 common crop species, due to surface $\mathrm{O}_{3}$ exposure by 2020 relative to 2000 .

The international Tropospheric Ozone Assessment Report (TOAR) establishes a state-of-the-art of global $\mathrm{O}_{3}$ metrics for climate change, human health and crop/ecosystem research (Lefohn et al., 2017). To assess the potential $\mathrm{O}_{3}$ risk and protect vegetation from $\mathrm{O}_{3}$, different metrics are used: the European and US standard (AOT40 and W126, respectively) are based on exposure-based metrics, while flux-based metrics have been introduced only recently (UNECE, 2010; Klingberg et al., 2014; EEA, 2015). Unlike the exposure-based metrics, which only rely on the surface $\mathrm{O}_{3}$ concentration, the flux-based metrics were developed to quantify the accumulation of damaging $\mathrm{O}_{3}$ taken up by vegetation through the stomata over a species-specific phenological time window. These metrics also provide an information-rich tool in assessing the relative effectiveness of air pollution control strategies in lowering surface $\mathrm{O}_{3}$ levels worldwide (Monks et al., 2015). By reducing plant photosynthesis and growth, high surface $\mathrm{O}_{3}$ levels will result in reduction in carbon storage by vegetation and, finally, an indirect radiative forcing as a consequence of the $\mathrm{CO}_{2}$ rising in the atmosphere (Sitch et al., 2007; Ainsworth et al., 2012). This rising $\mathrm{CO}_{2}$ reduces stomatal conductance, which decreases $\mathrm{O}_{3}$ flux into plants, leading to increased $\mathrm{O}_{3}$ levels in the air of 3-4 ppb during the growing season over the $\mathrm{NH}$ by doubling of $\mathrm{CO}_{2}$ concentration (Fiscus et al., 2005; Sanderson et al., 2007).

Projected changes in ground-level $\mathrm{O}_{3}$ vary considerably among models (Stevenson et al., 2006; Wild, 2007) and emission scenarios. In earlier studies, the emissions of $\mathrm{O}_{3}$ precursors were based on a high population growth, leading to very high projected surface $\mathrm{O}_{3}$ concentrations by 2100 (Stevenson et al., 2000; Zeng and Pyle, 2003; Shindell et al., 2006). The last emission scenarios, i.e. the Representative Concentration Pathways (RCPs), were developed as part of the Fifth
Assessment Report of the Intergovernmental Panel on Climate Change (Meinshausen et al., 2011; van Vuuren et al., 2011; Cubasch et al., 2013; Myhre et al., 2013). These scenarios include different assumptions on climate, energy access policies, and land cover and land use changes (Arneth et al., 2008; Kawase et al., 2011; Kirtman et al., 2013). Until now, studies on $\mathrm{O}_{3}$ pollution impacts on terrestrial ecosystems are either limited to a single model or to particular regions (e.g. Clifton et al., 2014; Rieder et al., 2015) and only a few applications of global or regional models under the new RCPs scenarios were carried out (Kelly et al., 2012). In the framework of the Atmospheric Chemistry and Climate Model Intercomparison Project (ACCMIP), different simulations were performed by Lamarque et al. (2013) and Young et al. (2013) from 16 global chemistry models.

A few issues about surface $\mathrm{O}_{3}$, such as a better understanding of spatial changes and a better assessment of $\mathrm{O}_{3}$ impacts worldwide, are still challenging. To overcome these issues, the aim of this study is to quantify, for the first time, the spatial and temporal changes in the projected potential $\mathrm{O}_{3}$ impacts on photosynthetic carbon assimilation of vegetation at the global scale by comparing the $\mathrm{O}_{3}$ potential injury at present with that expected at the end of the 21 st century from different global chemistry models. The purpose of this study is not to provide a quantitative estimation of the ecosystem injury due to $\mathrm{O}_{3}$ but to highlight the world areas at higher risk and changes by 2100 .

\section{Materials and methods}

\subsection{ACCMIP models and RCP scenarios}

The global chemistry models used in this work were developed under ACCMIP. A detailed description of the selected models and of the emission scenarios (i.e. RCPs) is included in the Supplement. ACCMIP models were widely validated and used to evaluate projected changes in atmospheric chemistry and air quality under different emission and climate assumptions (e.g. Lamarque et al., 2010; Prather et al., 2012; Bowman et al., 2013; Lee et al., 2013; Voulgarakis et al., 2013). Lamarque et al. (2013) and Young et al. (2013) provided the main characteristics of 16 models and details for the ACCMIP simulations. Although within ACCMIP 16 models are available, due to the lack of hourly $\mathrm{O}_{3}$ concentration here we only focus on six global chemistry models with different configurations as presented in Table 1.

The length of historical and RCP simulations varies between models, but for all models the historical runs cover a period centred around 2000, while the time slice of RCPs is centred around 2100 (Table 1). As for each model we compare the relative mean change between the historical and RCP simulations, a different length in the number of years used in the analysis, the uncertainty is limited. 
Table 1. Characteristics of the models, including simulation time slice, spatial resolution, simulated gas species and associated bibliographic references (from Lamarque et al., 2013 and Young et al., 2013). BC is black carbon, OC is organic carbon, SOA is secondary organic aerosols, DMS is dimethyl sulfide, CCM is chemistry climate model, CTM is chemistry transport model and CGCM is chemistry general circulation model.

\begin{tabular}{|c|c|c|c|c|c|c|}
\hline Models & Type & $\begin{array}{l}\text { Simulation } \\
\text { length }\end{array}$ & $\begin{array}{l}\text { Resolution } \\
\text { (lat/long) }\end{array}$ & $\begin{array}{l}\text { Number of vertical } \\
\text { pressure levels and } \\
\text { top level }\end{array}$ & Species simulated & References \\
\hline CESM-CAM & $\mathrm{CCM}$ & $\begin{array}{l}2000-2009 \text { and } \\
2100-2109\end{array}$ & $1.875 / 2.5$ & $\begin{array}{l}26 \text { levels } \\
3.5 \mathrm{hPa}\end{array}$ & $\begin{array}{l}16 \text { gas species; constant } \\
\text { present-day isoprene, soil } \mathrm{NO}_{x} \text {, } \\
\text { DMS and volcanic sulfur, } \\
\text { oceanic CO. }\end{array}$ & Lamarque et al. (2012) \\
\hline GFDL-AM3 & $\mathrm{CCM}$ & $\begin{array}{l}2001-2010 \text { and } \\
2101-2110\end{array}$ & $2.0 / 2.5$ & $\begin{array}{l}48 \text { levels } \\
0.017 \mathrm{hPa}\end{array}$ & $\begin{array}{l}81 \text { gas species; } \mathrm{SO}_{x}, \mathrm{BC}, \\
\mathrm{OC}, \mathrm{SOA}, \mathrm{NH}_{3}, \mathrm{NO}_{3} ; \text { con- } \\
\text { stant pre-industrial soil } \mathrm{NO}_{x} ; \\
\text { constant present-day soil and } \\
\text { oceanic } \mathrm{CO}, \text { and biogenic } \\
\text { VOC; climate-sensitive dust, } \\
\text { sea salt, and DMS. }\end{array}$ & $\begin{array}{l}\text { Donner et al. (2011) } \\
\text { Naik et al. (2012) }\end{array}$ \\
\hline GISS-E2-R & $\mathrm{CCM}$ & $\begin{array}{l}2000-2004 \text { and } \\
2101-2105\end{array}$ & $2.0 / 2.5$ & $\begin{array}{l}40 \text { levels } \\
0.14 \mathrm{hPa}\end{array}$ & $\begin{array}{l}51 \text { gas species; interactive } \\
\text { sulfate, } \mathrm{BC}, \mathrm{OC}, \text { sea salt, } \\
\text { dust, } \mathrm{NO}_{3}, \mathrm{SOA} \text {, alkenes; } \\
\text { constant present-day soil } \mathrm{NO}_{x} \text {; } \\
\text { climate-sensitive dust, sea salt, } \\
\text { and DMS; climate-sensitive } \\
\text { isoprene based on present-day } \\
\text { vegetation. }\end{array}$ & $\begin{array}{l}\text { Lee and Adams (2011) } \\
\text { Shindell et al. (2012) }\end{array}$ \\
\hline MIROC-CHEM & $\mathrm{CCM}$ & $\begin{array}{l}2000-2010 \text { and } \\
2100-2104\end{array}$ & $2.8 / 2.8$ & $\begin{array}{l}80 \text { levels } \\
0.003 \mathrm{hPa}\end{array}$ & $\begin{array}{l}58 \text { gas species; } \mathrm{SO}_{4}, \mathrm{BC}, \\
\mathrm{OC} ; \text { constant present-day } \\
\text { VOCs, soil-NO } \mathrm{NO}_{x} \text {, oceanic-CO; } \\
\text { climate-sensitive dust, sea salt } \\
\text { and DMS. }\end{array}$ & Watanabe et al. (2011) \\
\hline MOCAGE & CTM & $\begin{array}{l}2000-2003 \text { and } \\
2100-2103\end{array}$ & $2.0 / 2.0$ & $\begin{array}{l}47 \text { levels } \\
6.9 \mathrm{hPa}\end{array}$ & $\begin{array}{l}110 \text { gas species; constant } \\
\text { present-day isoprene, other } \\
\text { VOCs, oceanic } \mathrm{CO} \text { and soil } \\
\mathrm{NO}_{x} \text {. }\end{array}$ & $\begin{array}{l}\text { Josse et al. (2004) } \\
\text { Krinner et al. (2005) } \\
\text { Teyssèdre et al. (2007) }\end{array}$ \\
\hline UM-CAM & CGCM & $\begin{array}{l}2000-2005 \text { and } \\
2094-2099\end{array}$ & $2.50 / 3.75$ & $\begin{array}{l}19 \text { levels } \\
4.6 \mathrm{hPa}\end{array}$ & $\begin{array}{l}60 \text { gas species; constant } \\
\text { present-day biogenic isoprene, } \\
\text { soil } \mathrm{NO}_{x} \text {, biogenic and oceanic } \\
\mathrm{CO} \text {. }\end{array}$ & Zeng et al. $(2008,2010)$ \\
\hline
\end{tabular}

\subsection{Potential ozone injury on vegetation}

The $\mathrm{O}_{3}$ exposure-based index, i.e. AOT40 (ppb h), is a metric used to assess the potential $\mathrm{O}_{3}$ risk to vegetation from local to global scales (Emberson et al., 2014). In literature, AOT40 is computed as sum of the hourly exceedances above $40 \mathrm{ppb}$, for hours between 08:00 and 20:00 or for hours with a solar radiation exceeding $50 \mathrm{~W} \mathrm{~m}^{-2}$ over species-specific growing seasons (UNECE, 2010). Conventionally, two major growing season time windows are used, namely 6 months (April to September) for temperate climates, for example in Europe, and all-year round for Mediterranean, subtropical and tropical-type climates where vegetation is physiologically active all along the year (Paoletti et al., 2007).

UNECE (2010) supports the use of a growing season, but a fixed time window does not allow incorporating the changes in the growing season due to climate change and would thus not be well suited for investigating changes over time. A recent study over Europe showed how computing AOT40 only over the growing season (i.e. April-September) would lead to an underestimation of AOT40 up to $50 \%$ for conifer trees, while in the case of deciduous trees the underestimation is much smaller ( $<5 \%$, Anav et al., 2016). Also, it should be noted that in Anav et al. (2016) the AOT40 is computed year-round. We computed the AOT40 for a model grid for hours between 08:00 and 20:00 (local time) for all days of the year. Therefore, we computed AOT40 as follows:

$$
\text { AOT40 }=\int_{01 \text { jan }}^{31 \text { dec }} \int_{08: 00 \text { a.m. }}^{08: 00 \text { p.m. }} \max \left(\left(\left[\mathrm{O}_{3}\right]-40\right), 0\right) \cdot \mathrm{d} t,
$$


where $\left[\mathrm{O}_{3}\right]$ is hourly $\mathrm{O}_{3}$ concentration (ppb) simulated by the models at the lower model layer and $\mathrm{d} t$ is time step $(1 \mathrm{~h})$. The function "maximum" ensures that only values exceeding $40 \mathrm{ppb}$ are taken into account. For the protection of forests, a critical level of $5 \mathrm{ppm} \mathrm{h}$ calculated over the growing season is recommended by UNECE (2010). Within the 2008/50/CE Directive, the critical level for agricultural crops ( $3 \mathrm{ppmh}$ ) is adopted as the long-term objective value for the protection of vegetation by 2020 .

The current chemistry models cannot predict changes in phenology over time (Anav et al., 2017), and thus the growing season length is the same between the historical period and different RCPs. The use of a common fixed time window (08:00-20:00) all year-round at global level allows skipping the use of a latitude-dependent model, which would increase the level of complexity. Because the growing season is highly variable across the latitude, rather than introducing further uncertainties by using a single model to simulate the growing season at all latitudes, we applied a simplified approach here with a year-long growing season which should be considered as a worst-case scenario. This approach is valuable and can be easily applied at the global scale to compare the historical and projected potential risk to vegetation.

The $\mathrm{O}_{3}$ concentration to be used in AOT40 calculation should be at the top of the canopy; however, most of models used here provide $\mathrm{O}_{3}$ concentrations at $90-120 \mathrm{~m}$. Nevertheless, even if the $\mathrm{O}_{3}$ concentration is simulated at different elevations above the sea level, because for each model we compare the variation between present and future, the change is consistent because the elevation is the same. In the case of risk assessment, by calculating AOT40 year-round, an overestimation can be observed over polluted region of NH. Since the aim of this study is to compare how $\mathrm{O}_{3}$ stress to vegetation changes between historical period and future, even if the AOT40 is mis-estimated at a given model grid point, the relative mean change is consistent because we compared the changes in AOT40 at the same model grid point.

From the AOT40, a factor of risk for forests and crops can be computed (Anav et al., 2011; Proietti et al., 2016). Thus, the potential $\mathrm{O}_{3}$ impact on photosynthetic carbon assimilation $\left(\mathrm{IO}_{3}\right)$, in the worst-case scenario, is expressed through a dimensionless value as following:

$\mathrm{IO}_{3}=\alpha \times$ AOT40,

where $\alpha$ is an empirically derived $\mathrm{O}_{3}$ response coefficient representing the proportional change in net photosynthesis per unit of AOT40 (Anav et al., 2011). From the Global Land Cover Facility (GLCF) data at $1^{\circ}$ of spatial resolution, we grouped the vegetation in three categories: conifers, crops (including grassland) and deciduous (including tropical forests and shrubs) trees. Even dynamic global vegetation models make use of plant functional types rather than complex and specific vegetation to simulate shifts in potential vegetation as a response to shifts in climate (Sitch et al.,
2007). The relationships between cumulative ozone exposure and reductions in net photosynthesis vary among and even within species (Reich, 1987; Ollinger et al., 1997). Differences in response per unit uptake tend to be greater in magnitude between functional groups (e.g. hardwoods vs. conifers) where leaf structure and plant growth strategy differ most widely (Reich, 1987). The dimensionless coefficient for coniferous trees $\left(0.7 \times 10^{-6}\right)$ and crops $\left(3.9 \times 10^{-6}\right)$ are based on the regressions of the photosynthesis response to $\mathrm{O}_{3}$ (Reich, 1987), while the coefficient for deciduous trees $\left(2.6 \times 10^{-6}\right)$ is based on Ollinger et al. (1997). From simulated changes in the risk factor, we can highlight potential risk areas for vegetation.

\section{Results and discussion}

We show the simulated global $\mathrm{O}_{3}$ spatial pattern of mean annual $\mathrm{O}_{3}$ concentration at the lower model layer in Fig. 1 explaining AOT40 patterns. Then, in Fig. 2 we show and discuss the AOT40 spatial and temporal distribution from the ACCMIP models for the historical and RCPs simulations, and finally in Fig. 3 we show the percentage of variation of $\mathrm{IO}_{3}$, i.e. the change in the potential impact of $\mathrm{O}_{3}$ on photosynthetic carbon assimilation for the ACCMIP models computed comparing the RCPs simulations with historical runs. A detailed description of each figure, model by model, is included in the Supplement. Table 2 show the annual total emissions and changes of $\mathrm{CO}, \mathrm{NMVOCs}, \mathrm{NO}_{x}$, total lightning $\mathrm{NO}_{x}$ emissions $\left(\mathrm{LNO}_{x}\right)$ and global atmospheric methane $\left(\mathrm{CH}_{4}\right)$ burden for the historical simulations in each model. The averaged values (simulated percentage) of global, NH and Southern Hemisphere (SH) mean surface $\mathrm{O}_{3}$, AOT40 and $\mathrm{IO}_{3}$ are derived from averaging values over the global/NH/SH land areas only are presented in Table 3.

\subsection{Spatial pattern of historical ozone concentration and AOT40}

The highest surface $\mathrm{O}_{3}$ concentrations (Fig. 1) and potential $\mathrm{O}_{3}$ impacts (Fig. 2) are found in the $\mathrm{NH}$, highlighting a hemispheric asymmetry. AOT40 was used widely during the last 2 decades, not only in Europe but also in South America (Moura et al., 2014) and Asia (Hoshika et al., 2011), when environmental factors are not limiting, e.g. water availability, air temperature, solar radiation affecting stomata opening (Anav et al., 2016; De Marco et al., 2016).

The multi-model $\mathrm{O}_{3}$ mean concentration, averaged over the land points of the domain, is $37.9 \pm 4.3 \mathrm{ppb}$ in $\mathrm{NH}$ and $22.9 \pm 3.8 \mathrm{ppb}$ in $\mathrm{SH}$ (Table 3a). Over land surfaces, the $\mathrm{NH}$ extratropics (i.e. mid-latitudes beyond the tropics) have $65 \%$ more $\mathrm{O}_{3}$ than the $\mathrm{SH}$ extratropics (data not shown). Similarly, the highest AOT40 values are found in the NH, with an averaged AOT40 of $24.8 \pm 10.1 \mathrm{ppmh}$ in $\mathrm{NH}$ and $2.5 \pm 1.7 \mathrm{ppmh}$ in SH (Table 3a). 


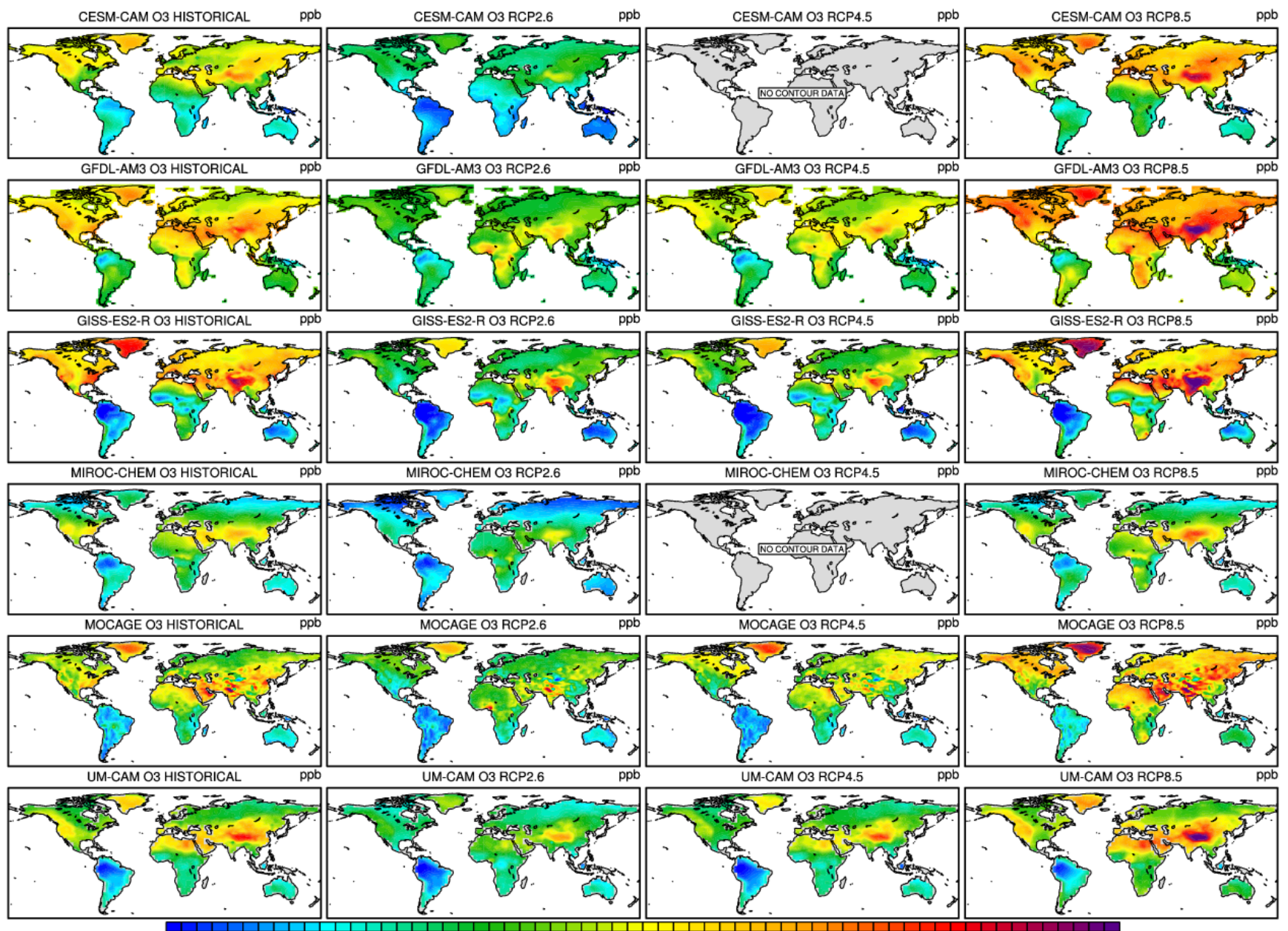

10121416182022242628303234363840424446485052545658606264666870

Figure 1. Surface ozone average concentrations (in ppb) at the lower model layer for each ACCMIP model over the historical period and for RCP2.6, RCP4.5 and RCP8.5 simulations by 2100 . The data are missing for two models under RCP4.5 ("no contour data").

According to previous studies, the annual mean background $\mathrm{O}_{3}$ concentrations at $\mathrm{NH}$ mid-latitude range between 35 and $50 \mathrm{ppb}$ during the end of the 20th century (e.g. Cooper et al., 2012; IPCC, 2014; Lefohn et al., 2014). Similarly, we found historical surface $\mathrm{O}_{3}$ mean concentrations ranging between 35 and $50 \mathrm{ppb}$ and between 35 and $50 \mathrm{ppmh}$ for AOT40 in the $\mathrm{NH}$, with the highest values occurring over Greenland and in the latitude band $15-45^{\circ} \mathrm{N}$, particularly around the Mediterranean basin, Near East, North America and over the Tibetan Plateau ( $>50 \mathrm{ppb}$ and $70 \mathrm{ppmh}$ ), while the lowest $\mathrm{O}_{3}$ burden $(15-30 \mathrm{ppb},<20 \mathrm{ppmh}$ ) was recorded in SH, particularly over Amazonian, African and Indonesian rainforests, where the $\mathrm{O}_{3}$ dry deposition rate is maximum, up to $1.80 \mathrm{~cm} \mathrm{~s}^{-1}$ for mixed wood forests (Wesely and Hicks, 2000). Tropospheric $\mathrm{O}_{3}$ has a significant source from stratospheric $\mathrm{O}_{3}$ (Parrish et al., 2012) and it can be transported by the large-scale Brewer-Dobson overturning circulation, i.e. an upward motion from the tropics and downward at higher latitudes, resulting in higher $\mathrm{O}_{3}$ concentrations in the extrat- ropics (Hudson et al., 2006; Seidel et al., 2008; Parrish et al., 2012). The six models are able to reproduce the spatial pattern of $\mathrm{O}_{3}$ concentration and thus AOT40 worldwide.

The highest historical $\mathrm{O}_{3}$ mean concentrations are observed in GFDL-AM3 and the lowest are found in MIROCCHEM. In the early 2000s, the maximum global $\mathrm{O}_{3}$ mean concentration (39 ppb) in GFDL-AM3 is associated to the lowest annual total $\mathrm{NO}_{x}$ emissions (46.2 Tg; Table 2a) and low $\mathrm{LNO}_{x}(4.4 \mathrm{Tg})$ while the minimum global $\mathrm{O}_{3}$ mean concentration (28 ppb) in MIROC-CHEM is related to the highest emissions of total $\mathrm{NO}_{x}$ per year $(57.3 \mathrm{Tg})$ and erroneously high $\mathrm{LNO}_{x}$ (9.7 Tg per year; Lamarque et al., 2013). MIROC-CHEM simulates 58 gaseous species in the chemical scheme with constant present-day biogenic VOCs emissions while GFDL-AM3 simulates 81 species (Stevenson et al., 2013; Lamarque et al., 2013). In GISS-E2-R, the hemispheric asymmetry in $\mathrm{O}_{3}$ is more important with e.g. a mean concentration of $22 \mathrm{ppb}$ in $\mathrm{SH}$ and $42 \mathrm{ppb}$ in $\mathrm{NH}$. A stronger global AOT40 mean $(26 \mathrm{ppmh})$ is observed in GISS-E2-R 


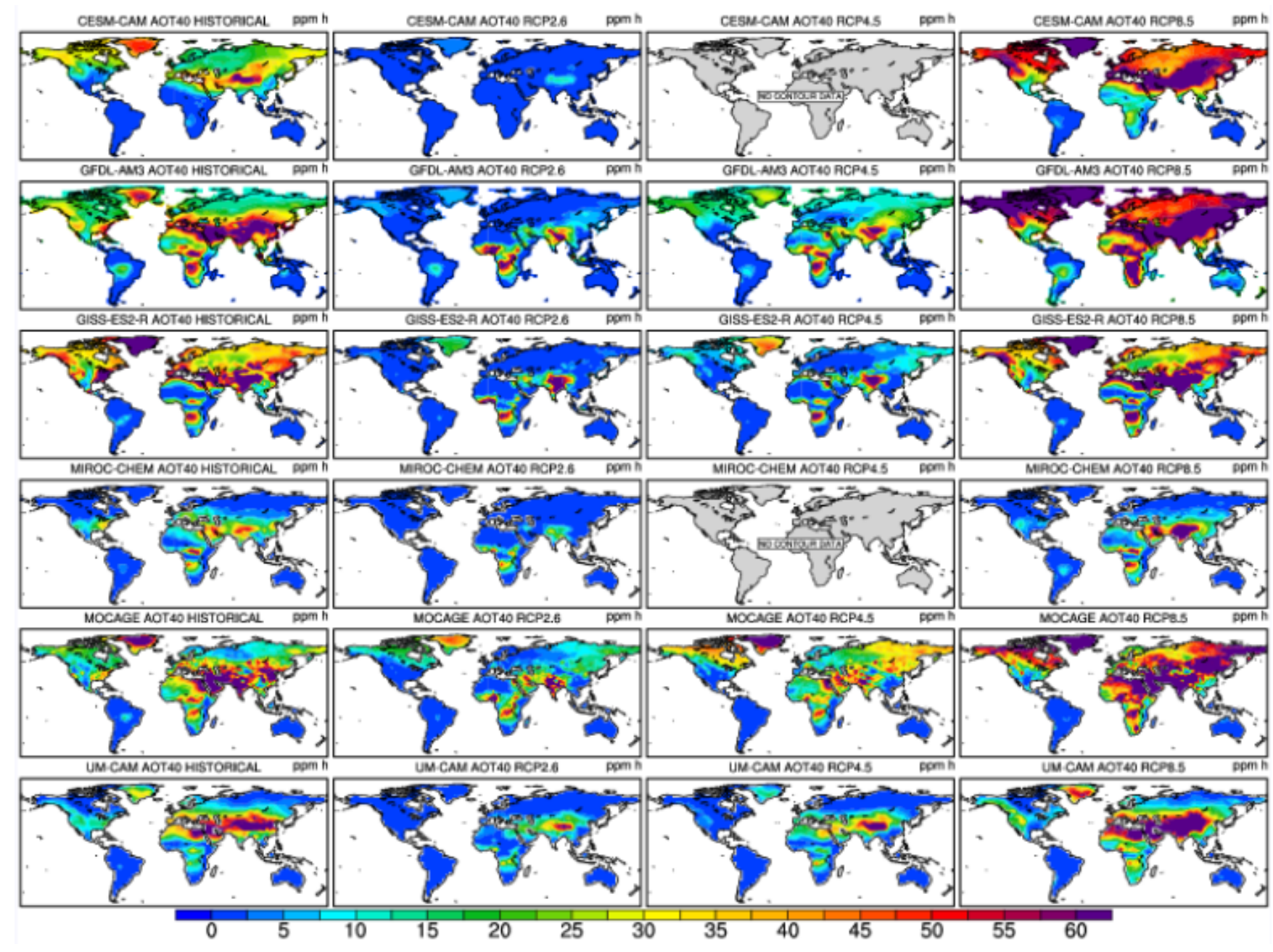

Figure 2. Surface mean AOT40 (in ppmh) at the lower model layer for each ACCMIP model over the historical period and for RCP2.6, RCP4.5 and RCP8.5 simulations by 2100. The data are missing for two models under RCP4.5 ("no contour data").

and the lowest (7 ppmh) in MIROC-CHEM for historical simulations. Model-to-model differences are observed due to different natural emissions of $\mathrm{O}_{3}$ precursors (e.g. lightning $\mathrm{NO}_{x}$ ) and the different chemical schemes used.

Higher $\mathrm{O}_{3}$ burdens (mean concentration $>50 \mathrm{ppb}$, AOT40 $>70 \mathrm{ppmh}$ ) are simulated at high-elevation areas, e.g. at Rocky and Appalachian mountains and over the Tibetan Plateau (Figs. 1 and 2). At high elevation, solar radiation, biogenic VOC emission, exchange between free troposphere and boundary layer and stratospheric $\mathrm{O}_{3}$ intrusion within the troposphere are more important that at the surface layer (Steinbacher et al., 2004; Kulkarni et al., 2011; Lefohn et al., 2012). Altitude reduces the $\mathrm{O}_{3}$ destruction by deposition and NO (Chevalier et al., 2007). In addition, due to the high elevation, ambient air remains colder and dryer in summer, leading to lower summertime $\mathrm{O}_{3}$ losses from photolysis (Helmig et al., 2007). The high-elevation areas, characterized by higher $\mathrm{O}_{3}$ burdens, are well simulated in GISS-E2-R and MOCAGE models.
The Tibetan Plateau, a so-called "ozone valley", is the highest plateau in the world, with a mean height of 4000 ma.s.l. (Tian et al., 2008) with strong thermal and dynamic influences on regional and global climate (Chen et al., 2011). High surface $\mathrm{O}_{3}$ mean concentrations (40-60 ppb) were reported in previous studies (e.g. Zhang et al., 2004; Bian et al., 2011; Guo et al., 2015; Wang et al., 2015). Although this region is remote, road traffic, biofuel energy source, coal mines and trash burning are prevalent. These pollution sources contribute to significant amount of $\mathrm{NO}_{x}$, $\mathrm{CO}$ and VOCs (Wang et al., 2015). The high $\mathrm{O}_{3}$ levels are attributed to the combined effects of high-elevation surface, thermal and dynamical forcing of the Tibetan Plateau and in situ photochemical production in the air trapped in the plateau by surrounding mountains (Guo et al., 2015; Wang et al., 2015). The dynamic effect, associated with the largescale circulation, is more important than the chemical effect (Tian et al., 2008; Liu et al., 2010) and responsible for the high $\mathrm{O}_{3}$ levels over the Tibetan Plateau. The six models are 
Table 2. (a) Annual total emissions of $\mathrm{CO}\left(\mathrm{TgCO}_{\mathrm{Cear}}{ }^{-1}\right)$, NMVOCs $\left(\mathrm{TgC}_{\text {year }}{ }^{-1}\right), \mathrm{NO}_{x}\left(\mathrm{Tg} \mathrm{Nyear}^{-1}\right.$, including lightning and soil $\left.\mathrm{NO}_{x}\right)$, total lightning $\mathrm{NO}_{x}$ emissions $\left(\mathrm{LNO}_{x}\right)$ and global atmospheric methane $\left(\mathrm{CH}_{4}\right)$ burden $(\mathrm{Tg})$ for the historical simulations in each model (from Young et al., 2013, and * from Voulgarakis et al., 2013). (b) Simulated percentage (\%) changes in total emissions of CO, $\mathrm{NMVOCs}^{*} \mathrm{NO}_{x}$ (including lightning and soil $\mathrm{NO}_{x}$ ), total lightning $\mathrm{NO}_{x}$ emissions $\left(\mathrm{LNO}_{x}\right)$ and global atmospheric $\mathrm{CH}_{4}$ burden for each model between 2100 and historical simulation for RCPs (from Young et al., 2013, and * Voulgarakis et al., 2013). The last row shows means and SDs. Missing or not available data are identified (n.a.).

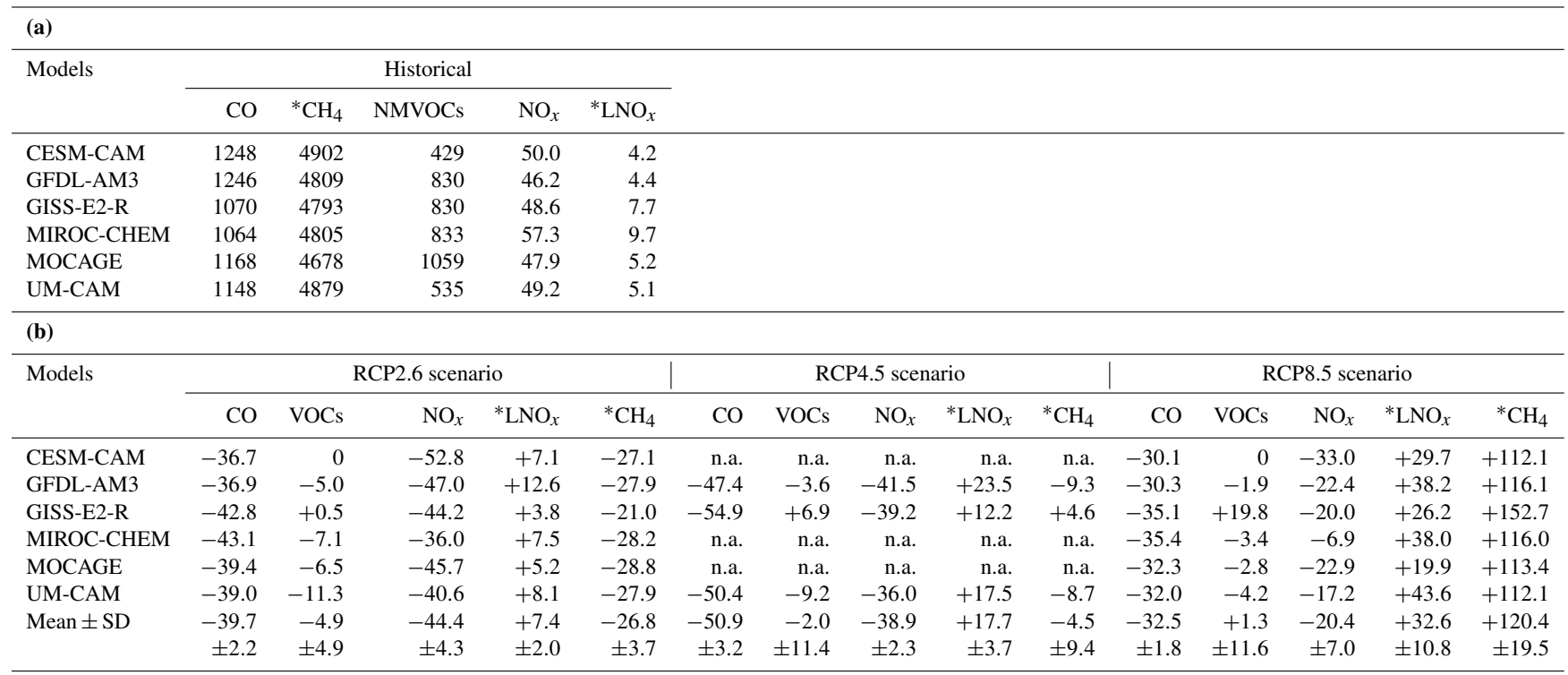

able to reproduce the high surface $\mathrm{O}_{3}$ mean concentrations (> $50 \mathrm{ppb}$ ) over the Tibetan Plateau.

Higher $\mathrm{O}_{3}$ mean concentrations $(>60 \mathrm{ppb})$ are also observed in southwestern USA, at the stations inland close to Los Angeles, in northeastern USA and eastern Asia (e.g. Beijing) in Fig. 1. The American southwest is an $\mathrm{O}_{3}$ precursor hotspot where the industrial sources emit $\mathrm{CH}_{4}$ and VOCs into the air (Jeričević et al., 2013) and the eastern and northern desert areas have higher ambient $\mathrm{O}_{3}$ concentrations than urban areas of southern California due to four factors: on-shore winds, gasoline reformulation, eastward population expansion and nighttime air chemistry (Arbaugh and Bytnerowicz, 2003). The surface concentrations show higher $\mathrm{O}_{3}$ levels in areas downwind of $\mathrm{O}_{3}$ precursor sources, i.e. urban and wellindustrialized areas, at distances of hundreds or even thousands of kilometres due to transport of $\mathrm{O}_{3}$ and precursors, including "reservoir" species such as peroxyacetyl nitrate (PAN), lower $\mathrm{O}_{3}$ titration by $\mathrm{NO}$ and higher biogenic VOC emission (Wilson et al., 2012; Paoletti et al., 2014; Monks et al., 2015; Sicard et al., 2016a). The higher $\mathrm{O}_{3}$ levels in areas downwind of $\mathrm{O}_{3}$ precursor sources are well simulated in GISS-E2-R and MOCAGE models.

Over Greenland, mean $\mathrm{O}_{3}$ concentrations during the historical runs ranged from 40 to $55 \mathrm{ppb}$ (Fig. 1) except in MIROC-CHEM (20-25 ppb). Similarly, Helmig et al. (2007) reported annual mean of surface $\mathrm{O}_{3}$ concentrations of $47 \mathrm{ppb}$ over Greenland between 2000 and 2005, particularly at the high-elevation Summit Station (3200 ma.s.1.). Several inves- tigations of snow photochemical and oxidation processes over Greenland concluded that photochemical $\mathrm{O}_{3}$ production can be attributed to high levels of reactive compounds (e.g. oxidized nitrogen species) present in the surface layer during the sunlit periods due to local sources, e.g. $\mathrm{NO}_{x}$ enhancement from snowpack emissions, PAN decomposition, boreal forest fires or ship emissions (Granier et al., 2006; Stohl et al., 2007; Legrand et al., 2009; Walker et al., 2012). The PAN to $\mathrm{NO}_{x}$ ratio increases with increasing altitude and latitude (Singh et al., 1992). The PAN reservoir for $\mathrm{NO}_{x}$ may be responsible for the increase in surface $\mathrm{O}_{3}$ concentrations at high latitudes (Singh et al., 1992). Local O $\mathrm{O}_{3}$ production does not appear to have an important contribution to the ambient high $\mathrm{O}_{3}$ levels (Helmig et al., 2007), but the long-range $\mathrm{O}_{3}$ transport can elevate the background concentrations measured at remote sites, e.g. Greenland (Ellingsen et al., 2008; Derwent et al., 2010). Low dry deposition rates for $\mathrm{O}_{3}$, from 0.01 to $0.05 \mathrm{~cm} \mathrm{~s}^{-1}$ over oceans and snow, the downward transport of stratospheric $\mathrm{O}_{3}$, the photochemical local production and the large-scale transport (Zhang et al., 2003; Legrand et al., 2009; Walker et al., 2012; Hess and Zbinden, 2013) are known factors to explain higher $\mathrm{O}_{3}$ pollution over Greenland.

The surface $\mathrm{O}_{3}$ concentrations $(>40 \mathrm{ppb})$ and AOT40 (> $60 \mathrm{ppmh}$ ) are higher over deserts, downwind of $\mathrm{O}_{3}$ precursor sources (e.g. Near East, Sierra Nevada, Colorado Desert), due to lower $\mathrm{O}_{3}$ dry deposition fluxes (Wesely and Hicks, 2000), $\mathrm{O}_{3}$ precursors long-range transport from urbanized ar- 
Table 3. (a) Global and hemispheric (averaged over the land points of the domain) mean annual-average surface ozone concentrations (in ppb) and mean AOT40 (in ppmh) for the historical simulations in each model (Northern and Southern hemispheres, i.e. NH and SH). The last row shows means and SDs. (b) Simulated percentage (\%) changes in global and hemispheric mean annual-average surface ozone concentrations (over the land points of the domain) and in global mean stratospheric ozone column (* from Voulgarakis et al., 2013) for each model between 2100 and historical simulation for RCPs (NH and SH). The last row shows means and SDs. Missing or not available data are identified (n.a.). (c) Simulated percentage (\%) changes in global and hemispheric mean AOT40 (over the land points of the domain) for each model between 2100 and historical simulation for RCPs (NH and SH). Missing or not available data are identified (n.a.). (d) Simulated percentage $(\%)$ changes in potential $\mathrm{O}_{3}$ impact on vegetation $\left(\mathrm{IO}_{3}\right.$, over the land points of the domain) for each model between 2100 and historical simulation for RCPs (NH and $\mathrm{SH}$ ). Missing or not available data are identified (n.a.).

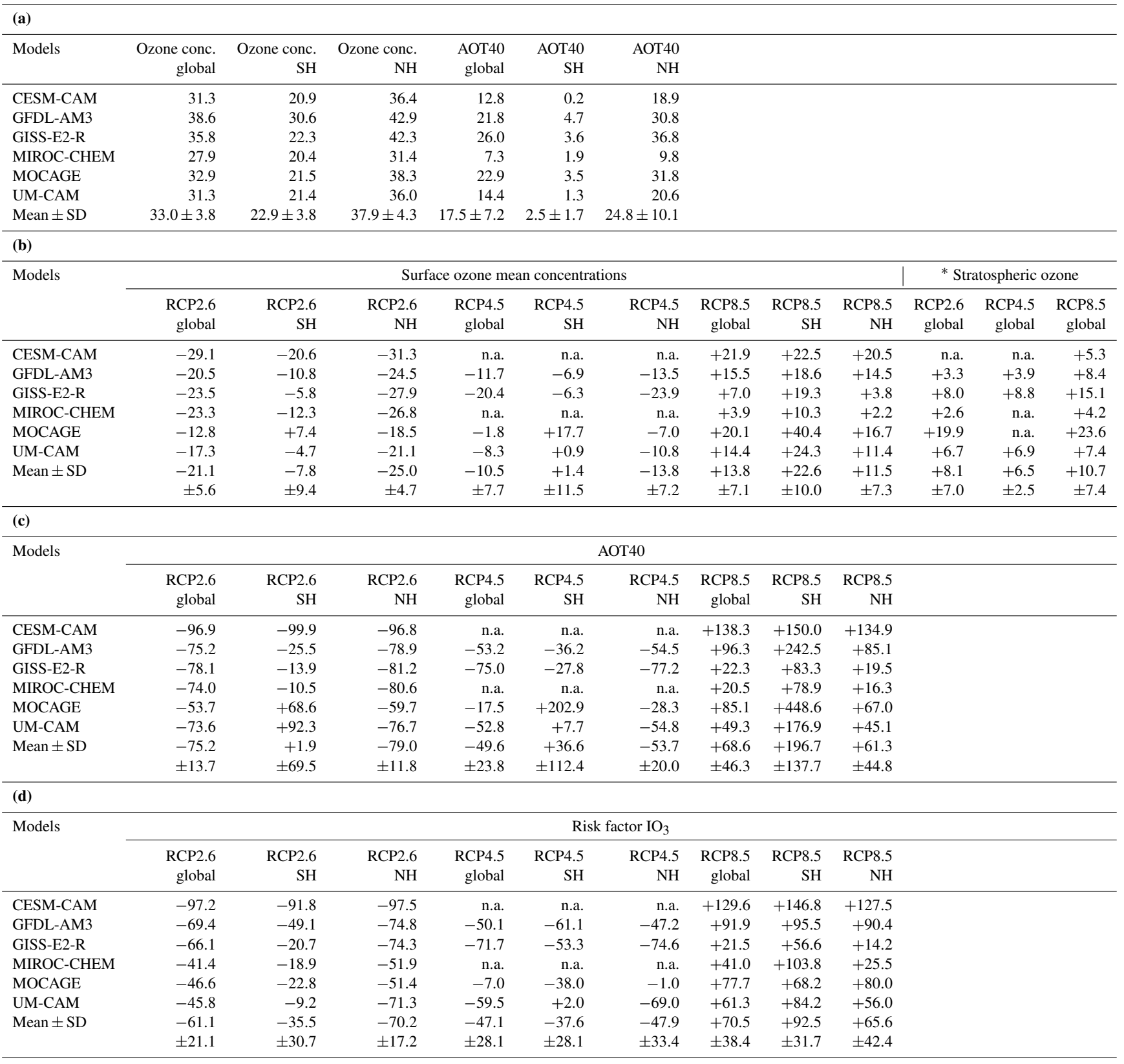

eas and high insolation. Around the Mediterranean basin, elevated AOT40 values ( $>60 \mathrm{ppm} \mathrm{h}$ ) are recorded, mainly due to the industrial development, road traffic increment, high insolation, sea-land breeze recirculation and long-range trans- port of $\mathrm{O}_{3}$ precursors and $\mathrm{O}_{3}$ (Sicard et al., 2013). All models, except MIROC-CHEM, reproduce well the high surface $\mathrm{O}_{3}$ mean concentrations over Greenland and over deserts. 


\subsection{Projected changes in ozone concentration and AOT40}

Recent studies display a mean global increase in background $\mathrm{O}_{3}$ concentration from a current level of $35-50 \mathrm{ppb}$ (e.g. IPCC, 2014; Lefohn et al., 2014) to 55-65 ppb (e.g. Wittig et al., 2007) and up to $85 \mathrm{ppb}$ at $\mathrm{NH}$ mid-latitudes by 2100 (IPCC, 2014). During the latter half of the 20th century surface $\mathrm{O}_{3}$ concentrations have increased markedly at $\mathrm{NH}$ midlatitudes (e.g. Oltmans et al., 2006; Parrish et al., 2012; Paoletti et al., 2014), mainly related to increasing anthropogenic precursor emissions related to economic growth of industrialized countries (e.g. Lamarque et al., 2005). Our results indicate that the future projections of the mean surface $\mathrm{O}_{3}$ concentrations and AOT40 vary considerably with the different scenarios and models (Figs. 1 and 2). The six models simulate a decrease of $\mathrm{O}_{3}$ concentration by 2100 under the RCP2.6 and RCP4.5 scenarios and an increase under the RCP8.5 scenario (Lamarque et al., 2011). In our study, the averaged relative changes in surface $\mathrm{O}_{3}$ concentration means (and AOT40) for the different RCPs are $-21 \%(-75 \%)$ for RCP2.6, $-10 \%(-50 \%)$ for RCP4.5 and $+14 \%$ (+ $69 \%$ ) for RCP8.5 with a strong disparity between both hemispheres, e.g. $-8 \%$ in SH and $-25 \%$ in NH for RCP2.6 (Table $3 \mathrm{~b}$ and c). RCP8.5 is the only scenario to show an increase in global background $\mathrm{O}_{3}$ levels by $2100(+23 \%$ in $\mathrm{SH}$ and $+11 \%$ in $\mathrm{NH}$ ).

Under the RCP2.6 scenario, all models predict that surface $\mathrm{O}_{3}$ will strongly decrease worldwide, except in equatorial Africa, where higher $\mathrm{O}_{3}$ levels are observed in GFDL-AM3, GISS-E2-R and MOCAGE. In CESM-CAM, GFDL-AM3 and MIROC-CHEM, a homogeneous decrease in $\mathrm{O}_{3}$ burden is simulated worldwide while in GISS-E2-R, MOCAGE and UM-CAM, the strongest decrease in surface $\mathrm{O}_{3}$ mean concentrations are found where high historical $\mathrm{O}_{3}$ concentrations were reported. Under RCP4.5 scenario, the surface $\mathrm{O}_{3}$ mean concentrations and AOT40 values are lower than historical runs worldwide for all models except in MOCAGE, where deterioration is observed over Canada, Greenland and eastern Asia. For all models, the surface $\mathrm{O}_{3}$ levels and AOT40 are higher for RCP8.5 as compared to historical runs and the highest increase is found in northwestern USA, Greenland, Mediterranean basin, Near East and eastern Asia. The AOT40 values, exceeding $70 \mathrm{ppmh}$, are found over the Tibetan Plateau, in the Near East and over Greenland. For RCP8.5, GFDL-AM3 is the most pessimistic model and MIROC-CHEM the most optimistic. By the end of the 21st century, similar patterns are evident for RCP4.5 compared to RCP2.6 and RCP4.5 simulation is intermediate between RCP2.6 and RCP8.5 scenarios.

For all models and RCPs, the $\mathrm{O}_{3}$ hotspots (mean concentrations $>50 \mathrm{ppb}$ and AOT40 $>70 \mathrm{ppmh}$ ) are over Greenland and southern Asia, in particular over the Tibetan Plateau. The highest increases are observed in $\mathrm{NH}$, in particular in northwestern USA, Greenland, Near East and south- ern Asia ( $>65 \mathrm{ppb}$ ). For the three RCPs, no significant change in ground-level $\mathrm{O}_{3}$ is observed in $\mathrm{SH}$ and the $\mathrm{SH}$ extratropics makes a small contribution to the overall change.

A recent global study showed the geographical patterns of surface air temperature differences for late 21 st century relative to the historical run (1986-2005) in all RCP scenarios (Nazarenko et al., 2015).The global warming in the RCP2.6 scenario is 2-3 times weaker than RCP4.5 scenario and 4-5 times weaker than RCP8.5 scenario (Nazarenko et al., 2015). For the three RCPs, the greatest change is observed over the Arctic, above latitude $60^{\circ} \mathrm{N}$ and in the latitude band 15$45^{\circ} \mathrm{N}$ (IPCC, 2014; Nazarenko et al., 2015). The weaker warming is simulated over the large area of the Southern Ocean. For RCP8.5 scenario, the global pattern of surface $\mathrm{O}_{3}$ levels and AOT40 (Figs. 1 and 2) is similar to surface air temperature increase distribution. For RCP8.5, significant increases in air temperature are simulated over latitude $60^{\circ} \mathrm{N}$ and over the Tibetan Plateau (more than $5^{\circ} \mathrm{C}$ ). An increase of $4-5{ }^{\circ} \mathrm{C}$ over the Near East, eastern and southern Asia, northern and southern Africa and Canada are simulated as well as $+1-3^{\circ} \mathrm{C}$ for the rest of the world (Nazarenko et al., 2015). The tropospheric warming is stronger in the latitude band $15-45^{\circ} \mathrm{N}$ (Seidel et al., 2008) and Hudson et al. (2006) have demonstrated that $\mathrm{O}_{3}$ trends over a 24-year period in the $\mathrm{NH}$ are due to trends observed in tropics and mid-latitudes areas and polar regions. The models are able to reproduce the global pattern of air temperature changes distribution in agreement with surface $\mathrm{O}_{3}$ concentrations changes.

The spread in precursor emissions (e.g. VOCs, $\mathrm{NO}_{x}$ and $\mathrm{CO}$ ) is due to the range of representation of biogenic emissions $\left(\mathrm{NO}_{x}\right.$ from soils and lightning, $\mathrm{CO}$ from oceans and vegetation) as well as the complexity of chemical schemes in particular for NMVOCs simulations (e.g. isoprene) from explicitly specified to fully interactive with climate. RCP2.6 scenario has the lowest $\mathrm{O}_{3}$ precursor concentrations, and RCP8.5 has relatively low $\mathrm{NO}_{x}, \mathrm{CO}$ and VOCs emissions but very high $\mathrm{CH}_{4}$ (Table 2b). The global emissions of $\mathrm{NO}_{x}(-44 \%)$, VOCs $(-5 \%) \mathrm{CO}(-40 \%)$ and $\mathrm{CH}_{4}$ burden $(-27 \%)$ decline, while $\mathrm{LNO}_{x}$ increases by e.g. $7 \%$ under RCP2.6 (Table 2b). The $\mathrm{CO}(-32 \%)$ and $\mathrm{NO}_{x}$ $(-20 \%)$ emissions have decreased while LNOX $(+33 \%)$, VOCs $(+1 \%)$ and $\mathrm{CH}_{4}$ burden have increased $(+120 \%)$ under RCP8.5 scenario (Table $2 b$ ). The GISS-E2-R model shows a greater degree of variation than other models, with a stronger increase in $\mathrm{CH}_{4}$ burden $(+153 \%)$ and in VOCs emissions $(+20 \%)$ for RCP8.5 (Table $2 b)$.

Excluding $\mathrm{CH}_{4}$ burden and VOCs emissions, all the RCP scenarios include reductions and redistributions of $\mathrm{O}_{3}$ precursor emissions throughout the 21 st century due to the air pollution control strategies worldwide. The changes in $\mathrm{CH}_{4}$ burden are due to the different climate policies in model assumptions. In RCP2.6, $\mathrm{CH}_{4}$ emissions decrease steadily throughout the century; in RCP4.5 they remain steady until 2050 and then decrease (Voulgarakis et al., 2013) and in RCP8.5 (no climate policy) it rapidly increases compared 
to 2000. Methane burdens are fixed in the models with no sources, except for the GISS-E2-R simulations in which surface $\mathrm{CH}_{4}$ emissions are used rather than $\mathrm{CH}_{4}$ concentrations (Shindell et al., 2013). The model chemical schemes are greatly different due mainly to the NMVOCs simulations (Young et al., 2013). Isoprene dominates the total NMVOCs emissions (Guenther et al., 1995). In contrast to other models with constant present-day isoprene emissions, the GISSES2-R simulations incorporate climate-driven isoprene emissions, with greater BVOC emissions by 2100 and a positive change in total VOCs emissions across RCPs, related to the positive correlation between air temperature and isoprene emission (e.g. Guenther et al., 2006; Arneth et al., 2011; Young et al., 2013).

For RCP2.6 and RCP4.5 scenarios, there is a widespread decrease in $\mathrm{O}_{3}$ in $\mathrm{NH}$ by 2100 . The overall decrease in $\mathrm{O}_{3}$ concentration and AOT40 means for RCP4.5 are about half of that between RCP2.6 and the historical simulation. For both scenarios, the changes are dominated by the decrease in $\mathrm{O}_{3}$ precursor emissions in the $\mathrm{NH}$ extratropics compared to historical simulations (Table 2b). In $\mathrm{NO}_{x}$-saturated areas, annual mean $\mathrm{O}_{3}$ will slightly increase as a result of a less efficient titration by $\mathrm{NO}$, but the overall $\mathrm{O}_{3}$ burden will decrease substantially at hemispheric scale over time (Gao et al., 2013; Querol et al., 2014; Sicard et al., 2016a). In RCP4.5, Gao et al. (2013) showed that the largest decrease in $\mathrm{O}_{3}$ (4$10 \mathrm{ppb}$ ) occurs in summer at mid-latitudes in the lower troposphere while the $\mathrm{O}_{3}$ concentrations undergo an increase in winter. During the warm period, the photochemistry plays a major role in the $\mathrm{O}_{3}$ production, suggesting that the reduction in surface $\mathrm{O}_{3}$ concentrations is in agreement with the large reduction in anthropogenic $\mathrm{O}_{3}$ precursor emissions (Sicard et al., 2016a) reducing the extent of regional photochemical $\mathrm{O}_{3}$ formation (e.g. Derwent et al., 2013; Simpson et al., 2014). Titration effect was also reported by Collette et al. (2012) over Europe as analysed from six chemistry transport models.

The $\mathrm{O}_{3}$ increase can be also driven by the net impacts of climate change, i.e. increase in stratospheric $\mathrm{O}_{3}$ intrusion, changing $\mathrm{LNO}_{x}$ and impacting reaction rates, through sea surface temperatures and relative humidity changes (Lau et al., 2006; Voulgarakis et al., 2013; Young et al., 2013).

Under the RCP8.5 scenario, the increase in surface $\mathrm{O}_{3}$ concentrations, by $14 \%$ on average, can be attributed to the higher $\mathrm{CH}_{4}$ emissions coupled with a strong global warming, exceeding $2{ }^{\circ} \mathrm{C}$, and a weakened NO titration by reducing $\mathrm{NO}_{x}$ emissions (Stevenson et al., 2013; Young et al., 2013). The global $\mathrm{CH}_{4}$ burden is 27 and $5 \%$ lower than 2000, for the RCP2.6 and RCP4.5 scenarios, respectively, while for RCP8.5 the total $\mathrm{CH}_{4}$ burden has more than doubled compared to early 2000s and $\mathrm{LNO}_{x}$ emissions increased by $33 \%$ (Table 2b). In addition, stronger increases are found over the high-elevation Himalayan Plateau reflecting increased exchange with the free troposphere or stratosphere (Lefohn et al., 2012; Schnell et al., 2016). Several studies reported an increase in the stratospheric $\mathrm{O}_{3}$ influx and higher stratospheric $\mathrm{O}_{3}$ levels in response to a warming climate (e.g. Hegglin and Shepherd, 2009; Zeng et al., 2010). The downwards $\mathrm{O}_{3}$ transport from the stratosphere is an important source of tropospheric $\mathrm{O}_{3}$ (Hsu and Prather, 2009; Tang et al., 2011); therefore, stratospheric $\mathrm{O}_{3}$ recovery also plays a partial role (e.g. $+11 \%$ for RCP8.5) in surface $\mathrm{O}_{3}$ burden pattern. As an example, in MOCAGE, a smaller reduction in global $\mathrm{O}_{3}$ mean concentrations $(-13 \%)$ and higher increase in stratospheric $\mathrm{O}_{3}$ inputs $(+20 \%)$ are observed for RCP2.6 (Table 3b). Similarly, for RCP8.5, the highest increases in $\mathrm{O}_{3}$ mean concentrations $(+23 \%)$ and stratospheric $\mathrm{O}_{3}(+24 \%)$ are recorded in MOCAGE. In addition, $\mathrm{LNO}_{x}$ emissions show significant upward trend from 2000 to 2100 , in particular for the strongest warming scenario (RPC8.5) with greater convective and lightning activity (e.g. Williams, 2009; Lamarque et al., 2013). For RCP8.5, a reduction in surface $\mathrm{O}_{3}$ concentrations is also simulated over the equatorial region, where the increased relative humidity, in a warmer climate, increases the $\mathrm{O}_{3}$ loss rate (e.g. Johnson et al., 1999; Zeng and Pyle, 2003).

For RCP2.6 and RCP4.5, absolute decreases are observed for the Mediterranean basin and the western USA due to less precursor emissions in the $\mathrm{NH}$ extratropics (e.g. reduction of 5-7 ppb over Europe). Smaller reduction in surface $\mathrm{O}_{3}$ levels in southern and eastern Asia highlight the smaller changes in $\mathrm{O}_{3}$ precursor emissions due to the recent emission growth in this region (e.g. Zhang et al., 2009; Xing et al., 2015). For $\mathrm{RCP} 8.5$, the high $\mathrm{O}_{3}$ increase (up to $10 \mathrm{ppb}$ ) in southern Asia can be attributed to substantial increase in $\mathrm{CH}_{4}$ emissions coupled with a strong global warming, exceeding $2{ }^{\circ} \mathrm{C}$, and a weakened $\mathrm{NO}$ titration and a greater stratospheric $\mathrm{O}_{3}$ influx (Kawase et al., 2011; Wild et al., 2012; Young et al., 2013).

\subsection{Risk areas for vegetation under RCP scenarios}

Figure 3 shows the changes in the potential $\mathrm{O}_{3}$ impact on photosynthetic carbon assimilation between present and future. It should be noted that a zero percentage of change (i.e. no change) for $\mathrm{IO}_{3}$ is simulated in sparsely vegetated regions (e.g. Gobi, Sahara, Near East, Western Plateau and Greenland), while the change can be higher than $100 \%$ when the historical $\mathrm{O}_{3}$ concentrations are lower than $40 \mathrm{ppb}$ (i.e. AOT $40=0$ and $\mathrm{IO}_{3}=0$ ) and the $\mathrm{O}_{3}$ concentrations exceed $40 \mathrm{ppb}$ under RCPs (i.e. AOT40 $>0, \mathrm{IO}_{3}>0$ ). If the AOT40 during the historical period is 0 then the percentage of change is undefined and we have considered and set these grid points as missing values.

The potential $\mathrm{O}_{3}$ impact for vegetation strongly decreases in NH for RCP2.6 except in MOCAGE, where a slight increase in the risk factor $(+15 \%)$ is simulated at high latitudes and in southern Asia. Conversely, the areas where the risk for vegetation increases $(>60 \%)$ occur over Africa $(+15$ to $+60 \%$ ) for all models except in CESM-CAM, where no change is observed across Africa. Under RCP4.5 scenario, 

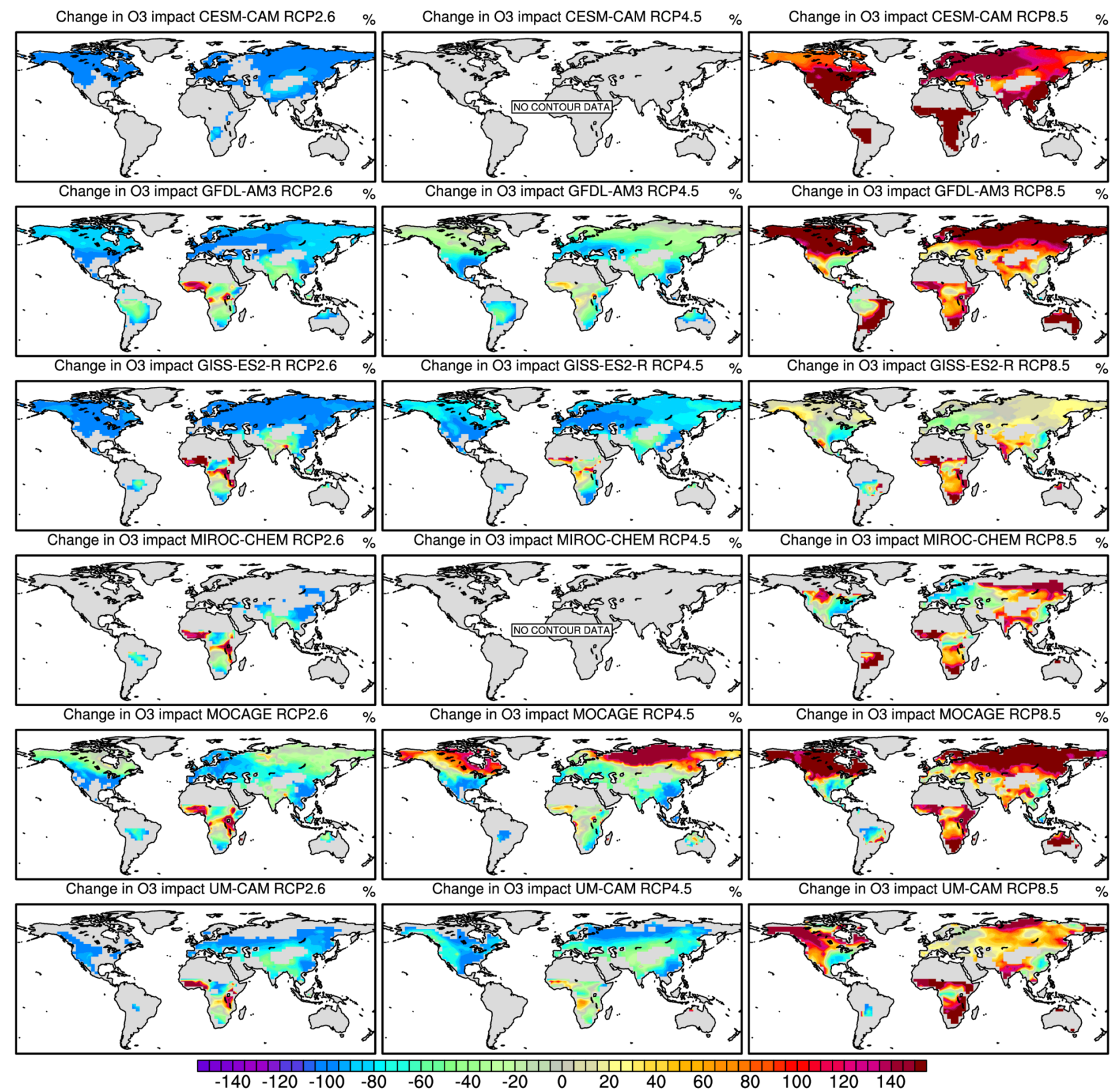

Figure 3. Simulated percentage changes $(\%)$ in the potential ozone impact on photosynthetic carbon assimilation (IO 3 ) for each ACCMIP model between RCP2.6, RCP4.5 and RCP8.5 simulations and the historical run. The data are missing for two models under RCP4.5 ("no contour data").

the strongest increase in potential risk for vegetation $(>+$ $60 \%$ ) is simulated by MOCAGE, markedly different from the other models, above the latitude $50^{\circ} \mathrm{N}$. For all models, the potential $\mathrm{O}_{3}$ impact for vegetation increases across Africa, from -15 to $+60 \%$, while slight decreases or no change occur over other parts of the world. Under RCP8.5 scenario, an increase of average $\mathrm{O}_{3}$ over a significant part of the domain is simulated; therefore the exposure to $\mathrm{O}_{3}$ pol- lution and impacts on vegetation will increase worldwide by 2100. An increase of the $\mathrm{O}_{3}$ impacts on vegetation is simulated in northern USA, South America, Asia and Africa, while a reduction in particular over eastern USA and southeastern China and a slight increase $(+15 \%)$ or decrease $(-15 \%)$ over Europe, depending on the model, are simulated. 
In summary, compared to the historical simulations, the averaged relative changes in the $\mathrm{O}_{3}$ risk factor for the different RCPs are $-61 \%$ for RCP2.6, $-47 \%$ for RCP4.5 and $+70 \%$ for RCP8.5 (Table 3d). We thus find a significant reduction in risk for vegetation for both RCP2.6 and RCP4.5 scenarios, except in South Africa and at high latitudes in MOCAGE simulations, and a strong increase in global risk under RCP8.5. Under RCP2.6 and RCP4.5 scenarios, $\mathrm{IO}_{3}$ slightly increases in Africa and over North America and Asia ( $>$ latitude $60^{\circ} \mathrm{N}$ ) in MOCAGE. The risk increases over the few areas where the $\mathrm{O}_{3}$ concentrations increased between the historical period and 2100. Under both scenarios, the strongest reductions in risk are observed over Amazon, central Africa and southern Asia, i.e. where the $\mathrm{O}_{3}$ concentrations have strongly declined between historical period and 2100. Under the RCP8.5, the areas where the highest projected $\mathrm{O}_{3}$ mean concentrations are simulated (e.g. Greenland and deserts) are not associated with an increase in $\mathrm{IO}_{3}$ due to the absence of vegetation. Under $\mathrm{RCP} 8.5, \mathrm{IO}_{3}$ increases worldwide while a reduction is simulated over southeastern North America, northern Amazon, central Africa and Southeast Asia, and a slighter reduction or a slight increase is simulated over western Europe (depending on the model).

The spatial pattern of $\mathrm{IO}_{3}$ is consistent with previous analyses of global environmental change (climate, land cover, nitrogen deposition and $\mathrm{CO}_{2}$ fertilization) impacts on vegetation (Nemani et al., 2003; Zhu et al., 2016), i.e. the highest reduction in risk for vegetation, in particular under RCP8.5, occurs over areas where a strong increase in greening, LAI and NPP is observed due to global changes and where a reduction in surface $\mathrm{O}_{3}$ mean concentrations is found by 2100 (Fig. 1). The regions with the largest greening trends are in southeastern North America, northern Amazon, Europe, central Africa and Southeast Asia with an average increase of the observed LAI exceeding $0.25 \mathrm{~m}^{2} \mathrm{~m}^{-2}$ per year (Zhu et al., 2016). The $\mathrm{CO}_{2}$ fertilization effects $(70 \%)$, nitrogen deposition $(9 \%)$ and climate change $(8 \%)$ explain the observed greening trend (Zhu et al., 2016). The changing climate alone produces persistent NPP increases and the regions with the highest increase in NPP, ranging from 1.0 to $1.5 \%$ per year, are in southeastern North America, northern Amazon, western Europe, central Africa and southern Asia (Nemani et al., 2003). From 1982 to 1999, the largest increase is observed in tropical regions, with more than $1.5 \%$ per year over the Amazon rainforest, which accounts for $42 \%$ of the global NPP increase (Nemani et al., 2003). The Amazon rainforest is one those regions where the effects are statistically significant. This is particularly important owing to the role of the Amazon rainforests in the global carbon cycle (Zhu et al., 2016). In these areas, we observed a strong increase in NPP and LAI due to warming climate while a reduction in GPP (from -10 to $-20 \%$ ) due to $\mathrm{O}_{3}$ is observed (Sitch et al., 2007). Inversely, the risk for vegetation $\mathrm{IO}_{3}$ increases in particular in Africa, e.g. western Africa along the Gulf of Guinea, in southern Brazil and over high-latitude regions $\left(>60^{\circ} \mathrm{N}\right)$ in
North America and Asia, where a reduction or a slight increase in LAI (from -0.05 to $+0.03 \mathrm{~m}^{2} \mathrm{~m}^{-2}$ per year) and strong decreases in NPP (1.0-1.5\% per year) are simulated (Nemani et al., 2003; Zhu et al., 2016).

Sitch et al. (2007) reported a high GPP reduction due to $\mathrm{O}_{3}$ effects, between 1901 and 2100 under the A2 emissions scenario of the Special Report on Emissions Scenarios, exceeding $30 \%$ in summer over western Europe, eastern North America, Amazon, central Africa and southern Asia. Previous studies have reported that the reductions in GPP simulated by Sitch et al. (2007) are overestimated up to 6 times due to the lack of empirical data about the response of different species to $\mathrm{O}_{3}$. Indeed, Sitch et al. (2007) focused on broad-leaved tree, needle-leaved tree, C 3 crops, $\mathrm{C} 4$ crops and shrubs. The fact that a few experiments have shown no response, e.g. grasslands (Bassin et al., 2013), and the noninclusion of the nitrogen limitation of growth are additional reasons of this overestimation (Zak et al., 2011; Kvaleveg and Myhre, 2013). In addition, the simulated $\mathrm{O}_{3}$ concentrations over Amazon forest exceed $90 \mathrm{ppb}$ in summer in Sitch et al. (2007), while the annual $\mathrm{O}_{3}$ mean is around $15-20 \mathrm{ppb}$ by 2100 in our study.

The projected land covers widely vary under RCPs (Betts et al., 2015). In the RCP2.6 scenario, the ground surface covered by croplands increases as a result of bioenergy production, with a more-or-less constant use of grassland. The RCP4.5 scenario focuses on global reforestation programs as part of global climate policy, as a result, the use of cropland and grassland decreases. Under RCP8.5, an increase in croplands and grasslands is applied mostly driven by an increasing global population (van Vuuren et al., 2011). About $50 \%$ of forests, grasslands and croplands might be exposed to high $\mathrm{O}_{3}$ levels by the end of the 21 st century (Sitch et al., 2007; Wittig et al., 2009).

Generally, deciduous broadleaf are highly $\mathrm{O}_{3}$-sensitive risk areas and needleleaf forests are moderately $\mathrm{O}_{3}$-sensitive risk areas. Crops and grasslands are more sensitive to $\mathrm{O}_{3}$ exposure than trees and deciduous trees are more sensitive than coniferous trees with lower stomatal conductance (Felzer et al., 2004; Ren et al., 2007; Wittig et al., 2009; Anav et al., 2011). Based on a comparison between Fig. 2 and the Global Land Cover Facility maps, we can observe that generally the AOT40, i.e. the potential $\mathrm{O}_{3}$ risk to vegetation, is high over shrublands (e.g. high-latitude region), broadleaf forests (e.g. central Africa), needleleaf forests (e.g. North America) and crops (e.g. southern Asia). Under RCP2.6 and RCP4.5, the risk decreases over areas covered by shrublands, savannas and slightly decreases over areas with needleleaf forests in North America and northern Asia. The risk strongly increases over broadleaf forest in Africa and the risk slightly decreases or slightly increases over grasslands (central Asia and central Africa and USA). Under RCP8.5, the largest decreases in risks occur in eastern USA, Europe and southeastern China, where the ground is mainly dominated by croplands, in all models except CESM-CAM. 


\section{Conclusions}

From six global atmospheric chemistry transport models, we illustrate the changes, i.e. differences for late 21 st century relative to the historical run, in ground-level $\mathrm{O}_{3}$ concentrations and vegetation impact metric (AOT40). Finally, the potential $\mathrm{O}_{3}$ impacts on photosynthetic carbon assimilation worldwide are investigated to define potential risk areas for vegetation at global scale by 2100 . A major advantage of this study is a comparison between models and scenarios to explore future potential $\mathrm{O}_{3}$ impacts.

The six models reproduce well the spatial pattern of historical $\mathrm{O}_{3}$ concentration and AOT40 at global scale; in particular GISS-E2-R and MOCAGE are able to simulate the higher $\mathrm{O}_{3}$ levels in areas downwind of precursor sources and at the high-elevation areas. The model outputs emphasize the strong asymmetry in the tropospheric $\mathrm{O}_{3}$ distribution between $\mathrm{NH}$ and $\mathrm{SH}$. The natural emissions of $\mathrm{O}_{3}$ precursors (e.g. lightning $\mathrm{NO}_{x}, \mathrm{CO}$ from oceans, isoprene) as well as the complexity of chemical schemes are significant sources of model-to-model differences.

Compared to early 2000s, the results suggest changes in surface $\mathrm{O}_{3}$ of $-9.5 \pm 2.0 \mathrm{ppb}(\mathrm{NH})$ and $-1.8 \pm 2.1 \mathrm{ppb}$ $(\mathrm{SH})$ in the cleaner RCP2.6 scenario and of $+4.4 \pm 2.8 \mathrm{ppb}$ $(\mathrm{NH})$ and $+5.1 \pm 2.1 \mathrm{ppb}(\mathrm{SH})$ in the RCP8.5 scenario. For RCP2.6 and RCP4.5, absolute decreases are observed for the Mediterranean basin and the western USA due to less precursor emissions in the NH extratropics. For RCP8.5, all models show climate-driven increases in ground-level $\mathrm{O}_{3}$ in particular over the western USA, Greenland, southern Asia and northeastern China and the changes ranged from +1 to $+5 \mathrm{ppb}$ over North America and Europe. This $\mathrm{O}_{3}$ increase can be mainly attributed to substantial increase in $\mathrm{CH}_{4}$ emissions coupled with a global warming and a weakened NO titration.

Most important results from the study are the spatial patterns and projected changes in global AOT40 and risk areas for vegetation under the RCP scenarios. Even if AOT40 was computed year-round, the global models suggest that, despite an improvement under RCP2.6 and RCP4.5, the AOT40based critical levels for the protection of forests and crops will be exceeded over many areas of the $\mathrm{NH}$ and they may be much more exceeded under RCP8.5 up to a factor exceeding 10 by 2100 .

Ozone may be a major threat to biodiversity over large regions of the world; however, the size of these areas remains uncertain. The potential $\mathrm{O}_{3}$ impact on carbon assimilation, $\mathrm{IO}_{3}$, provides a clear indicator of the potential risk to vegetation. By 2100 , the potential $\mathrm{O}_{3}$ impact on photosynthetic carbon assimilation decreases by 61 and $47 \%$ under RCP2.6 and RCP4.5, respectively, and increases by $70 \%$ under RCP8.5, compared to early 2000s over the whole domain. The strongest increase of the $\mathrm{O}_{3}$ impacts on vegetation is simulated in North America, northern Asia and central Africa. The highest reduction in risk for vegetation (i.e. southeastern North America, the northern Amazon, central Africa and Southeast Asia) occurs over areas where a strong increase in greening, LAI and NPP is observed and where a reduction in $\mathrm{O}_{3}$ mean concentrations is found by 2100 .

Many ecosystems worldwide are unprotected from $\mathrm{O}_{3}$ due to the lack of international efforts (Emberson et al., 2014). An efficient reduction in overall $\mathrm{O}_{3}$ levels is expected over North America and Europe in all RCP scenarios and worldwide if $\mathrm{CH}_{4}$ emissions are reduced (e.g. Kirtman et al., 2013; Pfister et al., 2014; Schnell et al., 2016). To efficiently protect vegetation against $\mathrm{O}_{3}$ pollution, suitable standards are urgently needed and the mitigation actions must be as part of international emission reduction programmes. The flux-based metric is introduced as new standard for vegetation protection against effects of $\mathrm{O}_{3}$ pollution, taking into account the detoxification processes and the modifying effects of multiple climatic and phenological factors on $\mathrm{O}_{3}$ uptake (Paoletti and Manning, 2007; Sicard et al., 2016b, c). Plant phenology plays a pivotal role in the climate system as it regulates the gas exchange between the biosphere and the atmosphere. Currently, in many $\mathrm{O}_{3}$ risk assessment studies, the phenology function is based on a simple latitude and topography model and the chemistry models do not take into account the shifts in plant phenology and in start and end date of the growing season; however, a first attempt to study the role of phenology on stomatal ozone uptake is shown by Anav et al. (2017).

Data availability. All data and figures are available in the Supplement and in this paper. No more data are available.

\section{The Supplement related to this article is available online at https://doi.org/10.5194/acp-17-12177-2017- supplement.}

Competing interests. The authors declare that they have no conflict of interest.

Acknowledgements. This work was carried out with the contribution of the LIFE financial instrument of the European Union (LIFE15 ENV/IT/183) in the framework of the MOTTLES project "Monitoring ozone injury for setting new critical levels" and published within the International Union of Forest Research Organizations (IUFRO) Task Force on Climate Change and Forest Health and IUFRO RG 7.01.09 "Ground-level ozone".

Edited by: Jayanarayanan Kuttippurath

Reviewed by: three anonymous referees 


\section{References}

Ainsworth, E. A., Yendrek, C. R., Sitch, S., Collins, W. J., and Emberson, L. D.: The effect of Tropospheric Ozone on net primary productivity and implications for climate change, Annu. Rev. Plant Biol., 63, 637-661, 2012.

Anav, A., Menut, L., Khvorostyanov, D., and Viovy, N.: Impact of tropospheric ozone on the Euro-Mediterranean vegetation, Glob. Change Biol., 17, 2342-2359, 2011.

Anav, A., De Marco, A., Proietti, C., Alessandri, A., Dell'Aquila, A., Cionni, I., Friedlingstein, P., Khvorostyanov, D., Menut, L., Paoletti, E., Sicard, P., Sitch, S., and Vitale, M.: Comparing concentration-based (AOT40) and stomatal uptake (PODY) metrics for ozone risk assessment to European forests, Global Change Biol., 22, 1608-1627, https://doi.org/10.1111/gcb.13138, 2016.

Anav, A., Liu, Q., De Marco, A., Proietti, C., Savi, F., Paoletti, E., and Piao, S.: The role of plant phenology in stomatal ozone flux modelling, Glob, Change Biol., https://doi.org/10.1111/gcb.13823, in press, 2017.

Arbaugh, M. J. and Bytnerowicz, A.: Ambient ozone patterns and effects over the Sierra Nevada: synthesis and implications for future research, in: Ozone Air Pollution in the Sierra Nevada: Distribution and Effects on Forests, Developments in Environmental Science, vol. 2, edited by: Bytnerowicz, A., Arbaugh, M., Alonso, R., Elsevier, Amsterdam, 249-261, 2003.

Arneth, A., Schurgers, G., Hickler, T., and Miller, P. A.: Effects of species composition, land surface cover, $\mathrm{CO}_{2}$ concentration and climate on isoprene emissions from European forests, Plant Biol., 10, 150-162, 2008.

Arneth, A., Schurgers, G., Lathiere, J., Duhl, T., Beerling, D. J., Hewitt, C. N., Martin, M., and Guenther, A.: Global terrestrial isoprene emission models: sensitivity to variability in climate and vegetation, Atmos. Chem. Phys., 11, 8037-8052, https://doi.org/10.5194/acp-11-8037-2011, 2011.

Ashmore, M. R.: Assessing the future global impacts of ozone on vegetation, Plant Cell Environ., 28, 949-964, 2005.

Ashworth, K., Wild, O., and Hewitt, C. N.: Impacts of biofuel cultivation on mortality and crop yields, Nat. Clim. Change, 3, 492496, 2013.

Bassin, S., Volk, M., and Fuhrer, J.: Species composition of subalpine grassland is sensitive to nitrogen deposition, but not ozone, after seven years of treatment, Ecosystems, 16, 1105-1117, 2013.

Betts, R. A., Golding, N., Gonzalez, P., Gornall, J., Kahana, R., Kay, G., Mitchell, L., and Wiltshire, A.: Climate and land use change impacts on global terrestrial ecosystems and river flows in the HadGEM2-ES Earth system model using the representative concentration pathways, Biogeosciences, 12, 1317-1338, https://doi.org/10.5194/bg-12-1317-2015, 2015.

Bian, J., Yan, R., Chen, H., Lü, D., and Massie, S. T.: Formation of the summertime ozone valley over the Tibetan Plateau: the Asian summer monsoon and air column variations, Adv. Atmos. Sci., 28, 1318-1325, 2011.

Bowman, K. W., Shindell, D. T., Worden, H. M., Lamarque, J. F., Young, P. J., Stevenson, D. S., Qu, Z., de la Torre, M., Bergmann, D., Cameron-Smith, P. J., Collins, W. J., Doherty, R., Dalsøren, S. B., Faluvegi, G., Folberth, G., Horowitz, L. W., Josse, B. M., Lee, Y. H., MacKenzie, I. A., Myhre, G., Nagashima, T., Naik, V., Plummer, D. A., Rumbold, S. T., Skeie, R. B., Strode, S.
A., Sudo, K., Szopa, S., Voulgarakis, A., Zeng, G., Kulawik, S. S., Aghedo, A. M., and Worden, J. R.: Evaluation of ACCMIP outgoing longwave radiation from tropospheric ozone using TES satellite observations, Atmos. Chem. Phys., 13, 40574072, https://doi.org/10.5194/acp-13-4057-2013, 2013.

Clifton, O. E., Fiore, A. M., Correa, G., Horowitz, L. W., and Naik, V.: Twenty-first century reversal of the surface ozone seasonal cycle over the northeastern United States, Geophys. Res. Lett., 41, 7343-7350, 2014.

Chen, X. L., Ma, Y. M., Kelder, H., Su, Z., and Yang, K.: On the behaviour of the tropopause folding events over the Tibetan Plateau, Atmos. Chem. Phys., 11, 5113-5122, https://doi.org/10.5194/acp-11-5113-2011, 2011.

Chevalier, A., Gheusi, F., Delmas, R., Ordóñez, C., Sarrat, C., Zbinden, R., Thouret, V., Athier, G., and Cousin, J.-M.: Influence of altitude on ozone levels and variability in the lower troposphere: a ground-based study for western Europe over the period 2001-2004, Atmos. Chem. Phys., 7, 4311-4326, https://doi.org/10.5194/acp-7-4311-2007, 2007.

Colette, A., Granier, C., Hodnebrog, Ø., Jakobs, H., Maurizi, A., Nyiri, A., Rao, S., Amann, M., Bessagnet, B., D’Angiola, A., Gauss, M., Heyes, C., Klimont, Z., Meleux, F., Memmesheimer, M., Mieville, A., Rouïl, L., Russo, F., Schucht, S., Simpson, D., Stordal, F., Tampieri, F., and Vrac, M.: Future air quality in Europe: a multi-model assessment of projected exposure to ozone, Atmos. Chem. Phys., 12, 10613-10630, https://doi.org/10.5194/acp-12-10613-2012, 2012.

Cooper, O. R., Sweeney, C., Gao, R. S., Tarasick, D., and Leblanc, T.: Long-term ozone trends at rural ozone monitoring sites across the United States, 1990-2010, J. Geophys. Res.Atmos., 117, D22307, https://doi.org/10.1029/2012JD018261, 2012.

Cooper, O. R., Parrish, D. D., Ziemke, J., Balashov, N. V., and Cupeiro, M.: Global distribution and trends of tropospheric ozone: an observation-based review, Elementa: Sci. Anthropocene, 2, 29, https://doi.org/10.12952/journal.elementa.000029, 2014.

Cubasch, U., Wuebbles, D., Chen, D., Facchini, M. C., Frame, D., Mahowald, N., and Winther, J. G.: Introduction, in Climate Change 2013: The Physical Science Basis. Contribution of Working Group I to the Fifth Assessment Report of the Intergovernmental Panel on Climate Change, edited by: Stocker, T. F., Qin, D., Plattner, G.-K., Tignor, M., Allen, S. K., Boschung, J., Nauels, A., Xia, Y., Bex, V., and Midgley, P. M., Cambridge Univ. Press, Cambridge, UK, and New York, 2013.

De Marco, A., Sicard, P., Vitale, M., Carriero, G., Renou, C., and Paoletti, E.: Metrics of ozone risk assessment for Southern European forests: canopy moisture content as a potential plant response indicator, Atmos. Environ., 120, 182-190, 2015.

Derwent, R. G., Witham, C. S., Utembe, S. R., Jenkin, M. E., and Passant, N. R.: Ozone in Central England: the impact of 20 years of precursor emission controls in Europe, Environ. Sci. Policy, 13, 195-204, 2010.

Derwent, R. G., Manning, A. J., Simmonds, P. G., Spain, T. G., and O'Doherty, S.: Analysis and interpretation of 25 years of ozone observations at the Mace Head Atmospheric Research Station on the Atlantic Ocean coast of Ireland from 1987 to 2012, Atmos. Environ., 80, 361-368, 2013.

Derwent, R. G., Utembe, S. R., Jenkin, M. E., and Shallcross, D. E.: Tropospheric ozone production regions and the intercontinen- 
tal origins of surface ozone over Europe, Atmos. Environ., 112, 216-224, 2015.

Donner, L. J., Wyman, B. L., Hemler, R. S., Horowitz, L. W., Ming, Y., Zhao, M., Golaz, J. C., Ginoux, P., Lin, S. J., Schwarzkopf, M. D., Austin, J., Alaka, G., Cooke, W. F., Delworth, T. L., Freidenreich, S. M., Gordon, C. T., Griffies, S. M., Held, I. M., Hurlin, W. J., Klein, S. A., Knutson, T. R., Langenhorst, A. R., Lee, H. C., Lin, Y., Magi, B. I., Malyshev, S. L., Milly, P. C. D., Naik, V., Nath, M. J., Pincus, R., Ploshay, J. J., Ramaswamy, V., Seman, C. J., Shevliakova, E., Sirutis, J. J., Stern, W. F., Stouffer, R. J., Wilson, R. J., Winton, M., Wittenberg, A. T., and Zeng, F.: The dynamical core, physical parameterizations, and basic simulation characteristics of the atmospheric component AM3 of the GFDL Global Coupled Model CM3, J. Climate, 24, 3484-3519, 2011.

European Environment Agency: Air quality in Europe 2015 report, Report No. 5/2015, Copenhagen, Denmark, https://doi.org/10.2800/62459, 2015.

Ellingsen, K., Gauss, M., Van Dingenen, R., Dentener, F. J., Emberson, L., Fiore, A. M., Schultz, M. G., Stevenson, D. S., Ashmore, M. R., Atherton, C. S., Bergmann, D. J., Bey, I., Butler, T., Drevet, J., Eskes, H., Hauglustaine, D. A., Isaksen, I. S. A., Horowitz, L. W., Krol, M., Lamarque, J. F., Lawrence, M. G., van Noije, T., Pyle, J., Rast, S., Rodriguez, J., Savage, N., Strahan, S., Sudo, K., Szopa, S., and Wild, O.: Global ozone and air quality: a multi-model assessment of risks to human health and crops, Atmos. Chem. Phys. Discuss., 8, 2163-2223, https://doi.org/10.5194/acpd-8-2163-2008, 2008.

Emberson, L. D., Fuhrer, J., Ainsworth, L., and Ashmore, M. R.: Biodiversity and Ground-level Ozone, Report UNEP/CBD/SBSTTA/18/INF/17, Convention on Biological Diversity, 18th Meeting, Montreal, 23-28 June 2014.

Felzer, B. S. F., Kicklighter, D. W., Melillo, J. M., Wang, C., Zhuan, Q. and Prinn, R. G.: Ozone effects on net primary production and carbon sequestration in the conterminous United States using a biogeochemistry model, Tellus B, 56, 230-248, 2004.

Fiscus, E. L., Booker, F. L., and Burkey, K. O.: Crop responses to ozone: uptake, modes of action, carbon assimilation and partitioning, Plant Cell Environ., 28, 997-1011, 2005.

Gao, Y., Fu, J. S., Drake, J. B., Lamarque, J.-F., and Liu, Y.: The impact of emission and climate change on ozone in the United States under representative concentration pathways (RCPs), Atmos. Chem. Phys., 13, 9607-9621, https://doi.org/10.5194/acp13-9607-2013, 2013.

Granier, C., Niemeier, U., Jungclaus, J. H., Emmons, L., Hess, P., Lamarque, J. F., Walters, S., and Brasseur, G. P.: Ozone pollution from future ship traffic in the Arctic northern passages, Geophys. Res. Lett., 33, L13807, https://doi.org/10.1029/2006GL026180, 2006.

Guenther, A. B., Hewitt, C. N., Erickson, D., Fall, R., Geron, C., Graedel, T., Harley, P., Klinger, L., Lerdau, M., Mckay, W. A., Pierce, T., Scholes, B., Steinbrecher, R., Tallamraju, R., Taylor, J., and Zimmerman, P.: A global model of natural volatile organic compound emissions, J. Geophys. Res.-Atmos., 100, 8873-8892, 1995.

Guenther, A., Karl, T., Harley, P., Wiedinmyer, C., Palmer, P. I., and Geron, C.: Estimates of global terrestrial isoprene emissions using MEGAN (Model of Emissions of Gases and
Aerosols from Nature), Atmos. Chem. Phys., 6, 3181-3210, https://doi.org/10.5194/acp-6-3181-2006, 2006.

Guo, D., Su, Y., Shi, C., Xunn, J., and Powell Jr., A. M.: Double core of ozone valley over the Tibetan Plateau and its possible mechanisms, J. Atmos. Sol.-Terr. Phy., 130, 127-131, 2015.

Hegglin, M. I. and Shepherd, T. G.: Large climate-induced changes in ultraviolet index and stratosphere-to-troposphere ozone flux, Nat. Geosci., 2, 687-691, https://doi.org/10.1038/ngeo604, 2009.

Helmig, D., Oltmans, S. J., Morse, T. O., and Dibb, J. E.: What is causing high ozone at Summit, Greenland?, Atmos. Environ., 41, 5031-5043, 2007.

Hess, P. G. and Zbinden, R.: Stratospheric impact on tropospheric ozone variability and trends: 1990-2009, Atmos. Chem. Phys., 13, 649-674, https://doi.org/10.5194/acp-13-649-2013, 2013.

Holland, M., Kinghorn, S., Emberson, L., Cinderby, S., Ashmore, M., Mills, G., and Harmens, H.: Development of a framework for probabilistic assessment of the economic losses caused by ozone damage to crops in Europe, UNECE International Cooperative Programme on Vegetation, Project Report Number C02309, NERC/Centre for Ecology and Hydrology, 50 pp., 2006.

Hoshika, Y., Shimizu, Y., and Omasa, K.: A comparison between stomatal ozone uptake and AOT40 of deciduous trees in Japan, iForest, 4, 128-135, https://doi.org/10.3832/ifor0573-004, 2011.

Hsu, J. and Prather, M. J.: Stratospheric variability and tropospheric ozone, J. Geophys. Res.-Atmos., 114, D06102, https://doi.org/10.1029/2008JD010942, 2009.

Hudson, R. D., Andrade, M. F., Follette, M. B., and Frolov, A. D.: The total ozone field separated into meteorological regimes Part II: Northern Hemisphere mid-latitude total ozone trends, Atmos. Chem. Phys., 6, 5183-5191, https://doi.org/10.5194/acp-65183-2006, 2006.

IPCC, Intergovernmental Panel on Climate Change: Summary for Policymakers, in: "Climate Change 2014: Impacts, Adaptation and Vulnerability". Contribution of Working Group II to the Fifth Assessment Report of the Intergovernmental Panel on Climate Change, Cambridge University Press, Cambridge, UK, 2014.

Jeričević, A., Koračin, D., Jiang, J., Chow, J., Watson, J., Fujita, E., and Minoura, H: Air Quality Study of High Ozone Levels in South California, in: Part of the series NATO Science for Peace and Security Series C: Environmental Security, Air Pollution Modeling and its Application XXII, edited by: Steyn, D. G., Builtjes, P. J. H., and Timmermans, R. M. A., 629-633, 2013.

Johnson, C. E., Collins, W. J., Stevenson, D. S., and Derwent, R. G.: Relative roles of climate and emissions changes on future tropospheric oxidant concentrations, J. Geophys. Res., 104, 18631$18645,1999$.

Josse, B., Simon, P., and Peuch, V. H.: Radon global simulations with the multiscale chemistry and transport model MOCAGE, Tellus B, 56, 339-356, 2004.

Kawase, H., Nagashima, T., Sudo, K., and Nozawa, T.: Future changes in tropospheric ozone under Representative Concentration Pathways (RCPs), Geophys. Res. Lett. 38, L05801, https://doi.org/10.1029/2010GL046402, 2011.

Kelly, J., Makar, P. A., and Plummer, D. A.: Projections of mid-century summer air-quality for North America: effects of changes in climate and precursor emissions, Atmos. 
Chem. Phys., 12, 5367-5390, https://doi.org/10.5194/acp-125367-2012, 2012.

Kirtman, B., Power, S. B., Adedoyin, J. A., Boer, G. J., Bojariu, R., Camilloni, I., Doblas-Reyes, F., Fiore, A. M., Kimoto, M., Meehl, G., Prather, M., Sarr, A., Schär, C., Sutton, R., van Oldenborgh, G. J., Vecchi, G., and Wang, H. J.: Near-term climate change: projections and predictability, in Climate Change 2013: The Physical Science Basis. Contribution of Working Group I to the Fifth Assessment Report of the Intergovernmental Panel on Climate Change, edited by: Stocker, T. F. et al., Cambridge Univ. Press, Cambridge, UK, and New York, 2013.

Klingberg, J., Engardt, M., Karlsson, P. E., Langner, J., and Pleijel, H.: Declining ozone exposure of European vegetation under climate change and reduced precursor emissions, Biogeosciences, 11, 5269-5283, https://doi.org/10.5194/bg-11-5269-2014, 2014.

Krinner, G., Viovy, N., de Noblet-Ducoudré, N., Ogée, J., Polcher, J., Friedlingstein, P., Ciais, P., Sitch, S., and Prentice, I. C.: A dynamic global vegetation model for studies of the coupled atmosphere-biosphere system, Global Biogeochem. Cy., 19, GB1015, https://doi.org/10.1029/2003GB002199, 2005.

Kulkarni, P. S., Bortoli, D., Salgado, R., Anton, M., Costa, M. J., and Silva, A. M.: Tropospheric ozone variability over the Iberian Peninsula, Atmos. Environ., 45, 174-182, 2011.

Kvalevag, M. M. and Myrhe, G.: The effect of carbon-nitrogen coupling on the reduced land carbon sink caused by ozone, Geophys. Res. Lett., 40, 3227-3231, 2013.

Lamarque, J. F., Hess, P. G., Emmons, L. K., Buja, L. E., Washington, W. M., and Granier, C.: Tropospheric ozone evolution between 1890 and 1990, J. Geophys. Res.-Atmos., 110, D08304, https://doi.org/10.1029/2004JD00553, 2005.

Lamarque, J.-F., Bond, T. C., Eyring, V., Granier, C., Heil, A., Klimont, Z., Lee, D., Liousse, C., Mieville, A., Owen, B., Schultz, M. G., Shindell, D., Smith, S. J., Stehfest, E., Van Aardenne, J., Cooper, O. R., Kainuma, M., Mahowald, N., McConnell, J. R., Naik, V., Riahi, K., and van Vuuren, D. P.: Historical (1850-2000) gridded anthropogenic and biomass burning emissions of reactive gases and aerosols: methodology and application, Atmos. Chem. Phys., 10, 7017-7039, https://doi.org/10.5194/acp-10-7017-2010, 2010.

Lamarque, J. F., Kyle, G. P., Meinshausen, M., Riahi, K., Smith, S. J., van Vuuren, D. P., Conley, A. J., and Vitt, F.: Global and regional evolution of short-lived radiatively-active gases and aerosols in the Representative Concentration Pathways, Climatic Change, 109, 191-212, https://doi.org/10.1007/s10584011-0155-0, 2011.

Lamarque, J.-F., Emmons, L. K., Hess, P. G., Kinnison, D. E., Tilmes, S., Vitt, F., Heald, C. L., Holland, E. A., Lauritzen, P. H., Neu, J., Orlando, J. J., Rasch, P. J., and Tyndall, G. K.: CAM-chem: description and evaluation of interactive atmospheric chemistry in the Community Earth System Model, Geosci. Model Dev., 5, 369-411, https://doi.org/10.5194/gmd-5369-2012, 2012.

Lamarque, J.-F., Shindell, D. T., Josse, B., Young, P. J., Cionni, I., Eyring, V., Bergmann, D., Cameron-Smith, P., Collins, W. J., Doherty, R., Dalsoren, S., Faluvegi, G., Folberth, G., Ghan, S. J., Horowitz, L. W., Lee, Y. H., MacKenzie, I. A., Nagashima, T., Naik, V., Plummer, D., Righi, M., Rumbold, S. T., Schulz, M., Skeie, R. B., Stevenson, D. S., Strode, S., Sudo, K., Szopa, S., Voulgarakis, A., and Zeng, G.: The Atmospheric Chemistry and
Climate Model Intercomparison Project (ACCMIP): overview and description of models, simulations and climate diagnostics, Geosci. Model Dev., 6, 179-206, https://doi.org/10.5194/gmd-6179-2013, 2013.

Langner, J., Engardt, M., Baklanov, A., Christensen, J. H., Gauss, M., Geels, C., Hedegaard, G. B., Nuterman, R., Simpson, D., Soares, J., Sofiev, M., Wind, P., and Zakey, A.: A multi-model study of impacts of climate change on surface ozone in Europe, Atmos. Chem. Phys., 12, 10423-10440, https://doi.org/10.5194/acp-12-10423-2012, 2012.

Lau, N. C., Leetmaa, A., and Nath, M. J.: Attribution of atmospheric variations in the 1997-2003 period to SST anomalies in the Pacific and Indian Ocean basins, J. Climate, 19, 3607-3628, 2006.

Lee, Y. H. and Adams, P. J.: A fast and efficient version of the twomoment aerosol sectional (TOMAS) global aerosol microphysics model, Aerosol Sci. Tech., 46, 678-689, 2011.

Lee, Y. H., Lamarque, J. F., Flanner, M. G., Jiao, C., Shindell, D. T., Berntsen, T., Bisiaux, M. M., Cao, J., Collins, W. J., Curran, M., Edwards, R., Faluvegi, G., Ghan, S., Horowitz, L. W., McConnell, J. R., Ming, J., Myhre, G., Nagashima, T., Naik, V., Rumbold, S. T., Skeie, R. B., Sudo, K., Takemura, T., Thevenon, F., Xu, B., and Yoon, J. H.: Evaluation of preindustrial to present-day black carbon and its albedo forcing from Atmospheric Chemistry and Climate Model Intercomparison Project (ACCMIP), Atmos. Chem. Phys., 13, 2607-2634, https://doi.org/10.5194/acp-13-2607-2013, 2013.

Lefohn, A. S., Shadwick, D., and Oltmans, S. J.: Characterizing changes in surface ozone levels in metropolitan and rural areas in the United States for 1980-2008 and 1994-2008, Atmos. Environ., 44, 5199-5210, 2010.

Lefohn, A. S., Wernli, H., Shadwick, D., Oltmans, S. J., and Shapiro, M.: Quantifying the frequency of stratospherictropospheric transport affecting enhanced surface ozone concentrations at high- and low-elevation monitoring sites in the United States, Atmos. Environ., 62, 646-656, 2012.

Lefohn, A. S., Emery, C., Shadwick, D., Wernli, H., Jung, J., and Oltmans, S. J.: Estimates of background surface ozone concentrations in the United States based on model-derived source apportionment, Atmos. Environ., 84, 275-288, 2014.

Lefohn, A. S., Malley, C. S., Simon, H., Wells, B., Xu, X., Zhang, L., and Wang, T.: Responses of human health and vegetation exposure metrics to changes in ozone concentration distributions in the European Union, United States, and China, Atmos. Environ., 152, 123-145, 2017.

Legrand, M.,Preunkert, S., Jourdain, B., Gallée, H., Goutail, F., Weller, R., and Savarino, J.: Year-round record of surface ozone at coastal (Dumont d'Urville) and inland (Concordia) sites in East Antarctica, J. Geophys. Res.-Atmos., 114, D20306, https://doi.org/10.1029/2008JD011667, 2009.

Liu, C., Liu, Y., Cai, Z., Gao, S., Bian, J., Liu, X., and Chance, K.: Dynamic formation of extreme ozone minimum events over the Tibetan Plateau during northern winters 1987-2001, J. Geophys. Res.-Atmos., 115, D18311, https://doi.org/doi:10.1029/2009JD013130, 2010.

Meinshausen, M., Wigley, T. M. L., and Raper, S. C. B.: Emulating atmosphere-ocean and carbon cycle models with a simpler model, MAGICC6 - Part 2: Applications, Atmos. Chem. Phys., 11, 1457-1471, https://doi.org/10.5194/acp-111457-2011, 2011. 
Mills, G., Hayes, F., Simpson, D., Emberson, L., Norris, D., Harmens, H., and Buker, P.: Evidence of widespread effects of ozone on crops and (semi-)natural vegetation in Europe (1990-2006) in relation to AOT40 and flux-based risk maps, Glob. Change Biol., 17, 592-613, 2011.

Monks, P. S., Archibald, A. T., Colette, A., Cooper, O., Coyle, M., Derwent, R., Fowler, D., Granier, C., Law, K. S., Mills, G. E., Stevenson, D. S., Tarasova, O., Thouret, V., von Schneidemesser, E., Sommariva, R., Wild, O., and Williams, M. L.: Tropospheric ozone and its precursors from the urban to the global scale from air quality to short-lived climate forcer, Atmos. Chem. Phys., 15, 8889-8973, https://doi.org/10.5194/acp-15-8889-2015, 2015.

Moura, B. B., Alves, E. S., de Souza, S. R., Domingos, M., and Vollenweider, P.: Ozone phytotoxic potential with regard to fragments of the Atlantic Semi-deciduous Forest downwind of Sao Paulo, Brazil, Environ. Pollut., 192, 65-73, 2014.

Myhre, G., Shindell, D., Bréon, F. M., Collins, W., Fuglestvedt, J., Huang, J., Koch, D., Lamarque, J. F., Lee, D., Mendoza, B., Nakajima, T., Robock, A., Stephens, G., Takemura, T., and Zhang, H.: Anthropogenic and natural radiative forcing, in: Climate Change 2013: The Physical Science Basis, Contribution of Working Group I to the Fifth Assessment Report of the Intergovernmental Panel on Climate Change, Cambridge University Press, Cambridge, UK and New York, USA, 2013.

Naik, V., Voulgarakis, A., Fiore, A. M., Horowitz, L. W., Lamarque, J.-F., Lin, M., Prather, M. J., Young, P. J., Bergmann, D., Cameron-Smith, P. J., Cionni, I., Collins, W. J., Dalsøren, S. B., Doherty, R., Eyring, V., Faluvegi, G., Folberth, G. A., Josse, B., Lee, Y. H., MacKenzie, I. A., Nagashima, T., van Noije, T. P. C., Plummer, D. A., Righi, M., Rumbold, S. T., Skeie, R., Shindell, D. T., Stevenson, D. S., Strode, S., Sudo, K., Szopa, S., and Zeng, G.: Preindustrial to present-day changes in tropospheric hydroxyl radical and methane lifetime from the Atmospheric Chemistry and Climate Model Intercomparison Project (ACCMIP), Atmos. Chem. Phys., 13, 5277-5298, https://doi.org/10.5194/acp13-5277-2013, 2013.

Nazarenko, L., Schmidt, G. A., Miller, R. L., Tausnev, N., Kelley, M., Ruedy, R., Russell, G. L., Aleinov, I., Bauer, M., Bauer, S., Bleck, R., Canuto, V., Cheng, Y., Clune, T. L., Del Genio, A. D., Faluvegi, G., Hansen, J. E., Healy, R. J., Kiang, N. Y., Koch, D., Lacis, A. A., Le Grande, A. N., Lerner, J., Lo, K. K., Menon, S., Oinas, V., Perlwitz, J., Puma, M. J., Rind, D., Romanou, A., Sato, M., Shindell, D. T., Sun, S., Tsigaridis, K., Unger, N., Voulgarakis, A., Yao, M. S., and Zhang, J.: Future climate change under RCP emission scenarios with GISS ModelE2, J. Adv. Model. Earth Sy., 7, 244-267, 2015.

Nemani, R. R., Keeling, C. D., Hashimoto, H., Jolly, W. M., and Piper, S. C.: Climate-driven increases in global terrestrial net primary production from 1982 to 1999 , Science, 300, 1560-1563, 2003.

Ochoa-Hueso, R., Munzi, S., Alonso, R., Arroniz-Crespo, M., Avila, A., Bermejo, V., Bobbink, R., Branquinho, C., Concostrina-Zubiri, L., Cruz, C., Cruz de Carvalho, R., De Marco, A., Dias, T., Elustondo, D., Elvira, S., Estebanez, B., Fusaro, L., Gerosa, G., Izquieta-Rojano, S., Lo Cascio, M., Marzuoli, R., Matos, P., Mereu, S., Merino, J., Morillas, L., Nunes, A., Paoletti, E., Paoli, L., Pinho, P., Rogers, I. B., Santos, A., Sicard, P., Stevens, C. J., and Theobald, M. R.: Ecological impacts of atmospheric pollution and interactions with climate change in terrestrial ecosystems of the Mediterranean Basin: current research and future directions, Environ. Pollut., 227, 194206, https://doi.org/10.1016/j.envpol.2017.04.062, 2017.

Ollinger, S. V., Aber, J. D., and Reich, P. B.: Simulating ozone effects on forest productivity: interactions among leaf, canopy, and stand-level processes, Ecol. Appl., 7, 1237-1251, 1997.

Oltmans, S. J., Lefohn, A. S., Harris, J. M., Galbally, I., Scheel, H. E., Bodeker, G., Brunke, E., Claude, H., Tarasick, D., Johnson, B. J., Simmonds, P., Shadwick, D., Anlauf, K., Hayden, K., Schmidlin, F., Fujimoto, T., Akagi, K., Meyer, C., Nichol, S., Davies, J., Redondas, A., and Cuevas, E.: Long-term changes in tropospheric ozone, Atmos. Environ., 40, 3156-3173, 2006.

Paoletti, E. and Manning, W. J.: Toward a biologically significant and usable standard for ozone that will also protect plants, Environ. Pollut., 150, 85-95, 2007.

Paoletti, E., De Marco, A., Beddows, D. C. S., Harrison, R. M., and Manning, W. J.: Ozone levels in European and USA cities are increasing more than at rural sites, while peak values are decreasing, Environ. Pollut., 192, 295-299, 2014.

Parrish, D. D., Law, K. S., Staehelin, J., Derwent, R., Cooper, O. R., Tanimoto, H., Volz-Thomas, A., Gilge, S., Scheel, H.-E., Steinbacher, M., and Chan, E.: Long-term changes in lower tropospheric baseline ozone concentrations at northern mid-latitudes, Atmos. Chem. Phys., 12, 11485-11504, https://doi.org/10.5194/acp-12-11485-2012, 2012.

Pfister, G. G., Walters, S., Lamarque, J. F., Fast, J., Barth, M. C., Wong, J., Done, J., Holland, G., and Bruyère, C. L.: Projections of future summertime ozone over the US, J. Geophys. Res.Atmos., 119, 5559-5582, 2014.

Prather, M., Bergmann, D., Cameron-Smith, P. J., Cionni, I., Collins, W. J., Dalsøren, S., Eyring, V., Folberth, G. A., Ginoux, P., Horowitz, L. W., Josse, B., Lamarque, J. F., MacKenzie, I. A., Nagashima, T., O’Connor, F. M., Righi, M., Rumbold, S. T., Shindell, D. T., Skeie, R. B., Sudo, K., Szopa, S., Takemura, T., and Zeng, G.: Global air quality and climate, Chem. Soc. Rev., 41, 6663-6683, https://doi.org/10.1039/C2CS35095E, 2012.

Proietti, C., Anav, A., De Marco, A., Sicard, P., and Vitale, M.: A multi-sites analysis on the ozone effects on Gross Primary Production of European forests, Sci. Total Environ., 556, 1-11, 2016.

Querol, X., Alastuey, A., Pandolfi, M., Reche, C., Pérez, N., Minguillón, M. C., Moreno, T., Viana, M., Escudero, M., Orio, A., Pallarés, M., and Reina, F.: 2001-2012 trends on air quality in Spain, Sci. Total Environ., 490, 957-969, 2014.

Reich, P. B.: Quantifying plant response to ozone: a unifying theory, Tree Physiol., 3, 63-91, 1987.

Ren, W., Tian, H., Liu, M., Zhang, C., Chen, G., Pan, S., Felzer, B., and Xu, X.: Effects of tropospheric ozone pollution on net primary productivity and carbon storage in terrestrial ecosystems of China, J. Geophys. Res.-Atmos., 112, 1-17, 2007.

Rieder, H. E., Fiore, A. M., Horowitz, L. W., and Naik, V.: Projecting policy-relevant metrics for high summertime ozone pollution events over the eastern United States due to climate and emission changes during the 21 st century, J. Geophys. Res.-Atmos., 120, 784-800, 2015.

Sanderson, M. G., Collins, W. J., Hemming, D. L., and Betts, R. A.: Stomatal conductance changes due to increasing carbon dioxide levels: projected impact on surface ozone levels, Tellus B, 59, 404-411, 2007. 
Schnell, J. L., Prather, M. J., Josse, B., Naik, V., Horowitz, L. W., Zeng, G., Shindell, D. T., and Falugevi, G.: Effect of climate change on surface ozone over North America, Europe, and East Asia, Geophys. Res. Lett., 43, 3509-3518, https://doi.org/10.1002/2016GL068060, 2016.

Seidel, D. J., Fu, Q., Randel, W. J., and Reichler, T. J.: Widening of the tropical belt in a changing climate, Nat. Geosci., 1, 21-4, 2008.

Shindell, D. T., Faluvegi, G., Stevenson, D. S., Krol, M. C., Emmons, L. K., Lamarque, J. F., Pétron, G., Dentener, F. J., Ellingsen, K., Schultz, M. G., Wild, O., Amann, M., Atherton, C. S., Bergmann, D. J., Bey, I., Butler, T., Cofala, J., Collins, W. J., Derwent, R. G., Doherty, R. M., Drevet, J., Eskes, H. J., Fiore, A. M., Gauss, M., Hauglustaine, D. A., Horowitz, L. W., Isaksen, I. S. A., Lawrence, M. G., Montanaro, V., Müller, J. F., Pitari, G., Prather, M. J., Pyle, J. A., Rast, S., Rodriguez, J. M., Sanderson, M. G., Savage, N. H., Strahan, S. E., Sudo, K., Szopa, S., Unger, N., van Noije, T. P. C., and Zeng, G.: Multi-model simulations of carbon monoxide: comparison with observations and projected near-future changes, J. Geophys. Res., 111, D19306, https://doi.org/10.1029/2006JD007100, 2006.

Shindell, D. T., Faluvegi, G., Koch, D. M., Schmidt, G. A., Unger, N., and Bauer, S. E.: Improved attribution of climate forcing to emissions, Science, 326, 716-718, https://doi.org/10.1126/science.1174760, 2009.

Shindell, D. T., Lamarque, J.-F., Schulz, M., Flanner, M., Jiao, C., Chin, M., Young, P. J., Lee, Y. H., Rotstayn, L., Mahowald, N., Milly, G., Faluvegi, G., Balkanski, Y., Collins, W. J., Conley, A. J., Dalsoren, S., Easter, R., Ghan, S., Horowitz, L., Liu, X., Myhre, G., Nagashima, T., Naik, V., Rumbold, S. T., Skeie, R., Sudo, K., Szopa, S., Takemura, T., Voulgarakis, A., Yoon, J.-H., and Lo, F.: Radiative forcing in the ACCMIP historical and future climate simulations, Atmos. Chem. Phys., 13, 2939-2974, https://doi.org/10.5194/acp-13-2939-2013, 2013.

Sicard, P., Coddeville, P., and Galloo, J. C.: Near-surface ozone levels and trends at rural stations in France over the 1995-2003 period, Environ. Monit. Assess., 156, 141-157, 2009.

Sicard, P., Vas, N., and Dalstein-Richier, L.: Annual and seasonal trends for ambient ozone concentration and its impact on forest vegetation in Mercantour National Park (South-eastern France) over the 2000-2008 period, Environ. Pollut., 159, 351-362, 2011.

Sicard, P., De Marco, A., Troussier, F., Renou, C., Vas, N., and Paoletti, E.: Decrease in surface ozone concentrations at Mediterranean remote sites and increase in the cities, Atmos. Environ., 79, 705-715, 2013.

Sicard, P., Serra, R., and Rossello, P.: Spatiotemporal trends of surface ozone concentrations and metrics in France, Environ. Res., 149, 122-144, 2016a.

Sicard, P, Augustaitis, A., Belyazid, S., Calfapietra, C., and De Marco, A.: Global topics and novel approaches in the study of air pollution, climate change and forest ecosystems, Environ. Pollut., 213, 977-987, 2016b.

Sicard, P., De Marco, A., Dalstein-Richier, L., Tagliaferro, F., and Paoletti, E.: An epidemiological assessment of stomatal ozone flux-based critical levels for visible ozone injury in Southern European forests, Sci. Total Environ., 541, 729-741, $2016 \mathrm{c}$.
Simpson, D., Arneth, A., Mills, G., Solberg, S., and Uddling, J.: Ozone - the persistent menace: interactions with the $\mathrm{N}$ cycle and climate change, Curr. Opin. Env. Sust., 9-10, 9-19, 2014.

Singh, H. B., Herlth, D., O'Hara, D., Zahnle, K., Bradshaw, J. D., Sandholm, S. T., Talbot, R., Crutzen, P. J., and Kanakidou, M.: Relationship of Peroxyacetyl nitrate to active and total odd nitrogen at northern high latitudes: influence of reservoir species on $\mathrm{NO}_{x}$ and $\mathrm{O}_{3}$, J. Geophys. Res.-Atmos., 97, 16523-16530, 1992.

Sitch, S., Cox, P. M., Collins, W. J., and Huntingford, C.: Indirect radiative forcing of climate change through ozone effects on the land-carbon sink, Nature, 448, 791-794, 2007.

Steinbacher, M., Henne, S., Dommen, J., Wiesen, P., and Prevot, A. S. H.: Nocturnal trans-alpine transport of ozone and its effects on air quality on the Swiss Plateau, Atmos. Environ., 38, 4539-4550, 2004.

Stevenson, D. S., Johnson, C. E., Collins, W. J., Derwent, R. G., and Edwards, J. M.: Future estimates of tropospheric ozone radiative forcing and methane turnover - the impact of climate change, Geophys. Res. Lett., 27, 2073-2076, 2000.

Stevenson, D. S., Dentener, F. J., Schultz, M. G., Ellingsen, K., van Noije, T. P. C., Wild, O., Zeng, G., Amann, M., Atherton, C. S., Bell, N., Bergmann D. J., Bey, I., Butler, T., Cofala, J., Collins, W. J., Derwent, R. G., Doherty, R. M., Drevet, J., Eskes, H. J., Fiore, A. M., Gauss, M., Hauglustaine, D. A., Horowitz, L. W., Isaksen, I. S. A., Krol, M. C., Lamarque, J. F., Lawrence, M. G., Montanaro, V., Müller, J. F., Pitari, G., Prather, M. J., Pyle, J. A., Rast, S., Rodriguez, J. M., Sanderson, M. G., Savage, N. H., Shindell, D. T., Strahan, S. E., Sudo, K., and Szopa, S.: Multi-model ensemble simulations of present-day and near-future tropospheric ozone, J. Geophys. Res.-Atmos., 111, D08301, https://doi.org/10.1029/2005JD006338, 2006.

Stevenson, D. S., Young, P. J., Naik, V., Lamarque, J.-F., Shindell, D. T., Voulgarakis, A., Skeie, R. B., Dalsoren, S. B., Myhre, G., Berntsen, T. K., Folberth, G. A., Rumbold, S. T., Collins, W. J., MacKenzie, I. A., Doherty, R. M., Zeng, G., van Noije, T. P. C., Strunk, A., Bergmann, D., Cameron-Smith, P., Plummer, D. A., Strode, S. A., Horowitz, L., Lee, Y. H., Szopa, S., Sudo, K., Nagashima, T., Josse, B., Cionni, I., Righi, M., Eyring, V., Conley, A., Bowman, K. W., Wild, O., and Archibald, A.: Tropospheric ozone changes, radiative forcing and attribution to emissions in the Atmospheric Chemistry and Climate Model Intercomparison Project (ACCMIP), Atmos. Chem. Phys., 13, 3063-3085, https://doi.org/10.5194/acp-13-3063-2013, 2013.

Stohl, A., Berg, T., Burkhart, J. F., Fjǽraa, A. M., Forster, C., Herber, A., Hov, Ø., Lunder, C., McMillan, W. W., Oltmans, S., Shiobara, M., Simpson, D., Solberg, S., Stebel, K., Ström, J., Tørseth, K., Treffeisen, R., Virkkunen, K., and Yttri, K. E.: Arctic smoke - record high air pollution levels in the European Arctic due to agricultural fires in Eastern Europe in spring 2006, Atmos. Chem. Phys., 7, 511-534, https://doi.org/10.5194/acp-7511-2007, 2007.

Tang, Q., Prather, M. J., and Hsu, J.: Stratosphere-troposphere exchange ozone flux related to deep convection, Geophys. Res. Lett., 38, L03806, https://doi.org/10.1029/2010GL046039, 2011.

Teyssèdre, H., Michou, M., Clark, H. L., Josse, B., Karcher, F., Olivié, D., Peuch, V.-H., Saint-Martin, D., Cariolle, D., Attié, J.-L., Nédélec, P., Ricaud, P., Thouret, V., van der A, R. J., VolzThomas, A., and Chéroux, F.: A new tropospheric and stratospheric Chemistry and Transport Model MOCAGE-Climat for 
multi-year studies: evaluation of the present-day climatology and sensitivity to surface processes, Atmos. Chem. Phys., 7, 58155860, https://doi.org/10.5194/acp-7-5815-2007, 2007.

Tian, W., Chipperfield, M., and Huang, Q.: Effects of the Tibetan Plateau on total column ozone distribution, Tellus B, 60, 622635, 2008

UNECE: United Nations Economic Commission for Europe. Convention on Long-Range Trans-boundary Air Pollution: Mapping Critical Levels for Vegetation. International Cooperative Programme on Effects of Air Pollution on Natural Vegetation and Crops, Bangor, UK, 2010.

van Vuuren, D., Edmonds, J., Kainuma, M., Riahi, K., Thomson, A., Hibbard, K., Hurtt, G. C., Kram, T., Krey, V., Lamarque, J. F., Masui, T., Meinshausen, M., Nakicenovic, N., Smith, S. J., and Rose, S. K.: The representative concentration pathways: an overview, Climatic Change, 109, 5-31, https://doi.org/10.1007/s10584-011-0148-z, 2011.

Voulgarakis, A., Naik, V., Lamarque, J.-F., Shindell, D. T., Young, P. J., Prather, M. J., Wild, O., Field, R. D., Bergmann, D., CameronSmith, P., Cionni, I., Collins, W. J., Dalsøren, S. B., Doherty, R. M., Eyring, V., Faluvegi, G., Folberth, G. A., Horowitz, L. W., Josse, B., MacKenzie, I. A., Nagashima, T., Plummer, D. A., Righi, M., Rumbold, S. T., Stevenson, D. S., Strode, S. A., Sudo, K., Szopa, S., and Zeng, G.: Analysis of present day and future $\mathrm{OH}$ and methane lifetime in the ACCMIP simulations, Atmos. Chem. Phys., 13, 2563-2587, https://doi.org/10.5194/acp13-2563-2013, 2013.

Walker, T. W., Jones, D. B. A., Parrington, M., Henze, D. K., Murray, L. T., Bottenheim, J. W., Anlauf, K., Worden, J. R., Bowman, K. W., Shim, C., Singh, K., Kopacz, M., Tarasick, D. W., Davies, J., von der Gathen, P., Thompson, A. M., and Carouge, C. C.: Impacts of mid-latitude precursor emissions and local photochemistry on ozone abundances in the Arctic, J. Geophys. Res.Atmos., 117, D01305, https://doi.org/10.1029/2011JD016370, 2012.

Wang, Q. Y., Gao, R. S., Cao, J. J., Schwarz, J. P., Fahey, D. W., Shen, Z. X., Hu, T. F., Wang, P., Xu, X. B., and Huang, R. J.: Observations of high level of ozone at Qinghai Lake basin in the northeastern Qinghai-Tibetan Plateau, western China, J. Atmos. Chem., 72, 19-26, 2015.

Wang, X. and Mauzerall, D. L.: Characterizing distributions of surface ozone and its impact on grain production in China, Japan and South Korea: 1900 and 2020, Atmos. Environ., 38, 43834402, 2004.

Watanabe, S., Hajima, T., Sudo, K., Nagashima, T., Takemura, T., Okajima, H., Nozawa, T., Kawase, H., Abe, M., Yokohata, T., Ise, T., Sato, H., Kato, E., Takata, K., Emori, S., and Kawamiya, M.: MIROC-ESM 2010: model description and basic results of CMIP5-20c3m experiments, Geosci. Model Dev., 4, 845-872, https://doi.org/10.5194/gmd-4-845-2011, 2011.

Wesely, M. L. and Hicks, B. B.: A review of the current status of knowledge in dry deposition, Atmos. Environ., 34, 2261-2282, 2000 .

Wild, O.: Modelling the global tropospheric ozone budget: exploring the variability in current models, Atmos. Chem. Phys., 7, 2643-2660, https://doi.org/10.5194/acp-7-2643-2007, 2007.

Wild, O., Fiore, A. M., Shindell, D. T., Doherty, R. M., Collins, W. J., Dentener, F. J., Schultz, M. G., Gong, S., MacKenzie, I. A., Zeng, G., Hess, P., Duncan, B. N., Bergmann, D. J., Szopa,
S., Jonson, J. E., Keating, T. J., and Zuber, A.: Modelling future changes in surface ozone: a parameterized approach, Atmos. Chem. Phys., 12, 2037-2054, https://doi.org/10.5194/acp12-2037-2012, 2012.

Williams, E. R.: The global electrical circuit: a review, Atmos. Res., 91, 140-152, 2009.

Wilson, R. C., Fleming, Z. L., Monks, P. S., Clain, G., Henne, S., Konovalov, I. B., Szopa, S., and Menut, L.: Have primary emission reduction measures reduced ozone across Europe? An analysis of European rural background ozone trends 1996-2005, Atmos. Chem. Phys., 12, 437-454, https://doi.org/10.5194/acp-12437-2012, 2012.

Wittig, V. E., Ainsworth, E. A., and Long, S. P.: To what extent do current and projected increases in surface ozone affect photosynthesis and stomatal conductance of trees? A meta-analytic review of the last 3 decades of experiments, Plant Cell Environ., 30, 1150-1162, 2007.

Wittig, V. E., Ainsworth, E. A., Naidu, S. L., Karnosky, D. F., and Long, S. P.: Quantifying the impact of current and future tropospheric ozone on tree biomass, growth, physiology and biochemistry: a quantitative meta-analysis, Glob. Change Biol., 15, 396-424, 2009.

Xing, J., Mathur, R., Pleim, J., Hogrefe, C., Gan, C.-M., Wong, D. C., Wei, C., Gilliam, R., and Pouliot, G.: Observations and modeling of air quality trends over 1990-2010 across the Northern Hemisphere: China, the United States and Europe, Atmos. Chem. Phys., 15, 2723-2747, https://doi.org/10.5194/acp-152723-2015, 2015.

Young, P. J., Archibald, A. T., Bowman, K. W., Lamarque, J.-F., Naik, V., Stevenson, D. S., Tilmes, S., Voulgarakis, A., Wild, O., Bergmann, D., Cameron-Smith, P., Cionni, I., Collins, W. J., Dalsøren, S. B., Doherty, R. M., Eyring, V., Faluvegi, G., Horowitz, L. W., Josse, B., Lee, Y. H., MacKenzie, I. A., Nagashima, T., Plummer, D. A., Righi, M., Rumbold, S. T., Skeie, R. B., Shindell, D. T., Strode, S. A., Sudo, K., Szopa, S., and Zeng, G.: Preindustrial to end 21 st century projections of tropospheric ozone from the Atmospheric Chemistry and Climate Model Intercomparison Project (ACCMIP), Atmos. Chem. Phys., 13, 20632090, https://doi.org/10.5194/acp-13-2063-2013, 2013.

Zak, D. R., Pregitzer, K. S., Kubiske, M. E., and Burton, A. J.: Forest productivity under elevated $\mathrm{CO}_{2}$ and $\mathrm{O}_{3}$; positive feedbacks to soil $\mathrm{N}$ cycling sustain decade-long net primary productivity enhancement by $\mathrm{CO}_{2}$, Ecol. Lett., 14, 1220-1226, 2011.

Zeng, G. and Pyle, J. A.: Changes in tropospheric ozone between 2000 and 2100 modeled in a chemistry-climate model, Geophys. Res. Lett., 30, 1392, https://doi.org/10.1029/2002GL016708, 2003.

Zeng, G., Pyle, J. A., and Young, P. J.: Impact of climate change on tropospheric ozone and its global budgets, Atmos. Chem. Phys., 8, 369-387, https://doi.org/10.5194/acp-8-369-2008, 2008.

Zeng, G., Morgenstern, O., Braesicke, P., and Pyle, J. A.: Impact of stratospheric ozone recovery on tropospheric ozone and its budget, Geophys. Res. Lett., 37, L09805, https://doi.org/10.1029/2010GL042812, 2010.

Zhang, L., Brook, J. R., and Vet, R.: A revised parameterization for gaseous dry deposition in air-quality models, Atmos. Chem. Phys., 3, 2067-2082, https://doi.org/10.5194/acp-3-2067-2003, 2003. 
Zhang, M., Xu, Y., Uno, I., and Akimoto, H.: A numerical study of tropospheric ozone in the springtime in east Asia, Adv. Atmos. Sci., 21, 163-170, 2004.

Zhang, Q., Streets, D. G., Carmichael, G. R., He, K. B., Huo, H., Kannari, A., Klimont, Z., Park, I. S., Reddy, S., Fu, J. S., Chen, D., Duan, L., Lei, Y., Wang, L. T., and Yao, Z. L.: Asian emissions in 2006 for the NASA INTEX-B mission, Atmos. Chem. Phys., 9, 5131-5153, https://doi.org/10.5194/acp-9-5131-2009, 2009.
Zhu, Z., Piao, S., Myneni, R. B., Huang, M., Zeng, Z., Canadell, J. G., Ciais, P., Sitch, S., Friedlingstein, P., Arneth, A., Cao, C., Cheng, L., Kato, E., Koven, C., Li, Y., Lian, X., Liu, Y., Liu, R., Mao, J., Pan, Y., Peng, S., Peñuelas, J., Poulter, B., Pugh, T. A. M., Stocker, B. D., Viovy, N., Wang, X., Wang, Y., Xiao, Z., Yang, H., Zaehle, S., and Zeng, N.: Greening of the Earth and its drivers, Nat. Clim. Change, 6, 791-795, 2016. 